\title{
Diversity and evolution of femoral variation in Ctenohystrica
}

\author{
Wilson, Laura A B ; Geiger, Madeleine
}

\begin{abstract}
Despite possessing a rather generalised postcranial skeleton, rodents are on average capable of a wide variety of locomotory behaviours, such as swimming, digging and climbing (Nowak, 1999). Particularly, rodents belonging to Ctenohystrica (sensu Huchon et al., 2002, and Fabre et al., 2012: Ctenodactylidae, Diatomyidae and Hystricognathi) display a diversity of locomotory styles and encompass a large range in body mass from approximately $50 \mathrm{~g}$ for the naked mole-rat Heterocephalus glaber to around $60 \mathrm{~kg}$ for the largest living rodent, the capybara Hydrochoerus hydrochaeris, consequently filling many different ecological niches (e.g. MacDonald, 2009; Wilson and Sánchez-Villagra, 2009, 2010). Moreover, this diversity is greatly expanded by the inclusion of giant extinct members such as Phoberomys, Arazamys and Josephoartigasia that reached body masses at least seven or eight times that of the capybara (Sánchez-Villagra et al., 2003; Rinderknecht and Blanco, 2008; Rinderknecht and Bostelmann, 2011). The adaptive diversity that characterises the evolution of Ctenohystrica, and particularly the Caviomorpha, a group that dispersed from Africa to colonise South America (Poux et al., 2006; Rowe et al., 2010) and evolved on that continent during a period of splendid isolation in the Cenozoic, has been the subject of numerous morpho-functional and evolutionary studies (e.g. Verzi et al., 2010; Wilson et al., 2010; Álvarez et al., 2011a, b; Hautier et al., 2011, 2012; Cox et al., 2012; Geiger et al., 2013; Wilson, 2013). The interplay between form and function has been studied in the postcranial skeleton of a number of mammals (e.g. Kappelman, 19; Anemone, 1990;White, 1993; Vizcaíno and Milne, 2002; Kley and Kearney, 2007; Meachen-Samuels, 2010), and studies of Ctenohystrica have, for example, examined individual bones (e.g. Seckel and Janis, 2008; Morgan, 2009; Steiner-Souza et al., 2010; Elissamburu and De Santis, 2011), long bones (Biknevicius, 1993; Elissamburu and Vizcaino, 2004; Samuels and Van Valkenburgh, 2008; Morgan and Álvarez, 2013) and the autopodial skeleton (e.g. Weisbecker and Schmid, 2007; Morgan and Verzi, 2011). These studies have used morphological traits, described as ratios or quantified using biomechanical indices or geometric morphometric descriptors of shape, to identify functional specialisations and instances of adaptive convergence underpinned by shared function and/or ecology.
\end{abstract}

DOI: https://doi.org/10.1017/CBO9781107360150.020

Posted at the Zurich Open Repository and Archive, University of Zurich

ZORA URL: https://doi.org/10.5167/uzh-121305

Book Section

Accepted Version

Originally published at:

Wilson, Laura A B; Geiger, Madeleine (2015). Diversity and evolution of femoral variation in Ctenohystrica. In: Cox, Philip G; Hautier, Lionel. Evolution of the Rodents. Cambridge: Cambridge University Press, 510-538.

DOI: https://doi.org/10.1017/CBO9781107360150.020 


\section{Evolution of the Rodents}

\section{Advances in Phylogeny, Functional Morphology and Development}

The widespread use of mouse models in developmental, behavioural and genetic studies has sparked wider interest in rodent biology as a whole. This book brings together the latest research on rodents to better understand the evolution of both living and extinct members of this fascinating group.

Topics analysed include the role of molecular techniques in the determination of robust phylogenetic framework; how geometric morphometric methods help quantify and analyse variation in shape; and the role of developmental biology in elucidating the origins of skeletal elements and the teeth. The editors unite these disciplines to present the current state of knowledge in rodent biology, whilst setting the landscape for future research.

This book highlights interdisciplinary links across palaeontology, developmental biology, functional morphology, phylogenetics and biomechanics, making it a valuable resource for evolutionary biologists in all fields.

Philip G. Cox is a lecturer at the Department of Archaeology, University of York, and the Hull York Medical School, and a researcher into the functional morphology of and evolution of mammals, particularly rodents. Much of his research has involved the application of sophisticated engineering techniques, namely finite element analysis, to rodent skulls and mandibles in order to understand the biomechanics of feeding in these species.

Lionel Hautier is a researcher (CR2) at the National Centre for Scientific Research (CNRS) posted at the Institut des Sciences de 1' Evolution de Montpellier (ISEM). He is a vertebrate palaeontologist, specialising in mammals and notably rodents. His research interests include the evolution of the masticatory apparatus of extinct and extant rodents, studied using morphological (osteological and myological), morphometrical and palaeontological evidence. 


\title{
Cambridge Studies in Morphology and Molecules: New Paradigms in Evolutionary Biology
}

\author{
SERIES EDITORS
}

Professor Russell L. Ciochon University of Iowa, USA

Dr Gregg F. Gunnell Duke University, USA

EDITORIAL BOARD

Dr Robert J. Asher University of Cambridge, UK

Professor Charles Delwiche University of Maryland, College Park, USA

Professor Todd Disotell New York University, USA

Professor S. Blair Hedges Pennsylvania State University, USA

Dr Michael Hofreiter Max Planck Institute, Leipzig, Germany

Professor Ivan Horáček Charles University in Prague, Czech Republic

Professor Jukka Jernvall University of Helsinki, Finland

Dr Zerina Johanson Natural History Museum, London, UK

Dr Shigeru Kuratani Riken Center for Developmental Biology, Japan

Dr John M. Logsdon University of Iowa, USA

Dr Johannes Müller Humboldt University of Berlin, Germany

Dr Patrick O'Connor Ohio University, USA

Dr P. David Polly Indiana University, USA

Dr Miriam Zelditch University of Michigan, USA

This new Cambridge series addresses the interface between morphological and molecular studies in living and extinct organisms. Areas of coverage include evolutionary development, systematic biology, evolutionary patterns and diversity, molecular systematics, evolutionary genetics, rates of evolution, new approaches in vertebrate palaeontology, invertebrate palaeontology, palaeobotany and studies of evolutionary functional morphology. The series invites proposals demonstrating innovative evolutionary approaches to the study of extant and extinct organisms that include some aspect of both morphological and molecular information. In recent years the conflict between 'molecules vs. morphology' has given way to more open consideration of both sources of data from each side making this series especially timely. 


\section{Carnivoran Evolution: New Vierws on Phylogeny, Form and Function}

Edited by Anjali Goswami and Anthony Friscia

Evolutionary History of Bats: Fossils, Molecules and Morphology

Edited by Gregg F. Gunnell and Nancy B. Simmons

Evolution of the House Mouse

Edited by Miloš Macholán, Stuart J. E. Baird, Pavel Munclinger and Jaroslav Piálek

From Clone to Bone: The Synergy of Morphological and Molecular Tools in Paleobiology

Edited by Robert J. Asher and Johannes Müller 


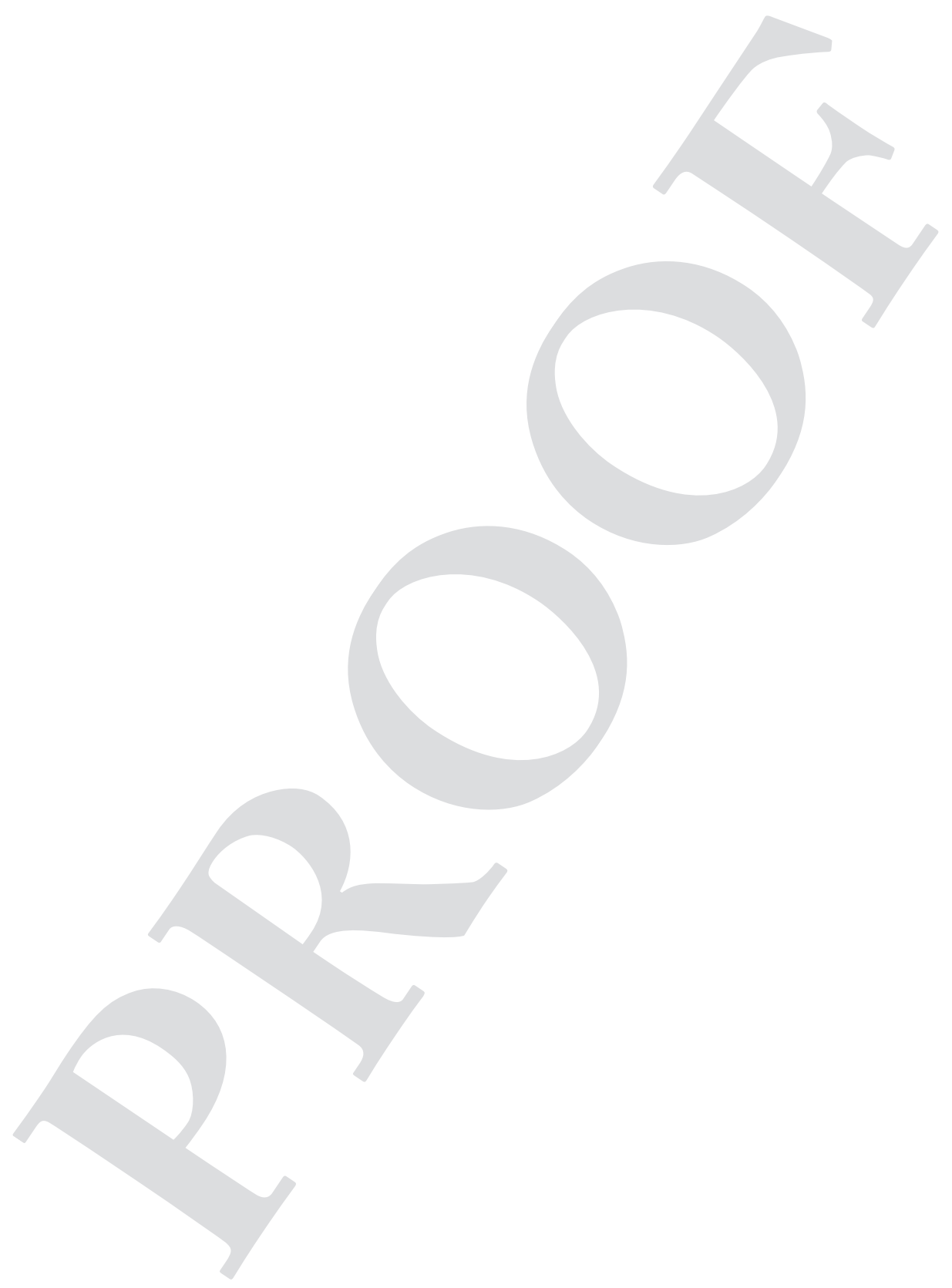




\section{Evolution of the Rodents}

\section{Advances in Phylogeny, Functional Morphology and Development}

EDITED BY

Philip G. Cox Department of Archaeology, University of York, and the Hull York Medical School

and

Lionel Hautier Institut des Sciences de l' Evolution de Montpellier (ISEM), Université de Montpellier 2 


\section{CAMBRIDGE UNIVERSITY PRESS}

University Printing House, Cambridge $\mathrm{CB}_{2}$ 8BS, United Kingdom

Cambridge University Press is part of the University of Cambridge.

It furthers the University's mission by disseminating knowledge in the pursuit of education, learning and research at the highest international levels of excellence.

www.cambridge.org

Information on this title: www.cambridge.org/9781107044333

(C) Cambridge University Press 2015

This publication is in copyright. Subject to statutory exception and to the provisions of relevant collective licensing agreements, no reproduction of any part may take place without the written permission of Cambridge University Press.

First published 2015

Printed in the United Kingdom by $[\mathrm{XX}]$

A catalogue record for this publication is available from the British Library

Library of Congress Cataloguing in Publication data

ISBN 978-I-IO7-04433-3 Hardback

Cambridge University Press has no responsibility for the persistence or accuracy of URLs for external or third-party internet websites referred to in this publication, and does not guarantee that any content on such websites is, or will remain, accurate or appropriate. 


\section{Contents}

List of contributors

page ix

Foreword

xiii

I Rodentia: a model order?

LIONEL HAUTIER AND PHILIP G. COX

2 A synopsis of rodent molecular phylogenetics, systematics and biogeography

PIERRE-HENRI FABRE，LIONEL HAUTIER AND EMMANUEL

J.P. DOUZERY

3 Emerging perspectives on some Paleocene sciurognaths rodents in Laurasia: the fossil record and its interpretation MARY R. DAWSON

4 Phylogeny and evolutionary history of hystricognathous rodents from the Old World during the Tertiary: new insights into the emergence of modern "phiomorph" families.

FRANCK BARBIÈRE AND LAURENT MARIVAUX

5 The history of South American octodontoid rodents and its contribution to evolutionary generalisations

DIEGO H. VERZI, CECILIA C. MORGAN AND A. ITATÍ OLIVARES

6 History, taxonomy and palaeobiology of the giant fossil rodents (Hystricognathi, Dinomyidae)

ANDRÉS RINDERKNECHT AND R. ERNESTO BLANCO

7 Advances in integrative taxonomy and the evolution of African murid rodents: how morphological trees hide the molecular forest CHRISTIANE DENYS AND ALISA WINKLER

8 Themes and variation in sciurid evolution

V. LOUISE ROTH AND JOHN M. MERCER

9 Marmot evolution and global change in the past Io million years

P. DAVID POLLY, ANDREA CARDINI, EDWARD B. DAVIS AND SCOTT STEPPAN 
Io Grades and clades among rodents: the promise of geometric morphometrics LIONEL HAUTIER, PHILIP G. COX AND RENAUD LEBRUN

II Biogeographic variations in wood mice: testing for the role of morphological variation as a line of least resistance to evolution. SABRINA RENAUD, JEAN-PIERRE QUÉRÉ AND JOHAN R. MICHAUX

I2 The oral apparatus of rodents: variations on the theme of a gnawing machine

ROBERT E. DRUZINSKY

I3 The muscles of mastication in rodents and the function of the medial pterygoid

PHILIP G. COX AND NATHAN JEFFERY

I4 Functional morphology of rodent middle ears

MATTHEW J. MASON

I5 Variations and anomalies in rodent teeth and their importance for testing developmental models

CYRIL CHARLES AND LAURENT VIRIOT

I6 The great variety of dental structures and dynamics in rodents: new insights into their ecological diversity HELDER GOMES RODRIGUES

I7 Convergent evolution of molar morphology in Muroidea (Rodentia, Mammalia): connections between chewing movements and crown morphology

VINCENT LAZZARI, FRANCK GUY, PIERRE-EMMANUEL SALAIS, ADÉlä̈DE EURIAT, CYRIL CHARLES, LAURENT VIRIOT, PAUL TAFFOREAU AND JACQUES MICHAUX

I8 Developmental mechanisms in the evolution of phenotypic traits in rodent teeth ELODIE RENVOISÉ AND SOPHIE MONTUIRE

I9 Diversity and evolution of femoral variation in Ctenohystrica LAURA A. B. WILSON AND MADELEINE GEIGER

20 Morphological disparity of the postcranial skeleton in rodents and its implications for palaeobiological inferences: the case of the extinct Theriodomyidae (Rodentia, Mammalia)

MONIQUE VIANEY-LIAUD, LIONEL HAUTIER AND LAURENT MARIVAUX

Index

Colour plate section between pages ooo-0oo 


\section{Contributors}

\section{Franck Barbière}

Institut des Sciences de l'Évolution de Montpellier, Universite Montpellier 2, Montpellier, France

\section{R. Ernesto Blanco}

Instituto de Física, Facultad de Ciencias, Montevideo, Uruguay

\section{Andrea Cardini}

Dipartimento di Biologia, Universitá di Modena e Reggio Emilia, Modena, Italy

\section{Cyril Charles}

Institut de Génomique Fonctionnelle de Lyon, Ecole Normale Supérieure de Lyon, Lyon, France

\section{Philip G. Cox}

Hull York Medical School, University of Hull, Hull, UK

\section{Edward B. Davis}

Museum of Natural and Cultural History and Department of Geology, University of Oregon, Eugene, OR, USA

\section{Mary R. Dawson}

Carnegie Museum of Natural History, Pittsburgh, PA, USA

\section{Christiane Denys}

Department of Systematics and Evolution, Muséum National d'Histoire Naturelle, Paris, France

\section{Emmanuel J. P. Douzery}

Institut des Sciences de l'Évolution de Montpellier, Universite Montpellier 2, Montpellier, France

\section{Robert E. Druzinsky}

Department of Oral Biology, College of Dentistry, University of Illinois at Chicago, Chicago, IL, USA

\section{Adélaïde Euriat}

Institut de Paléoprimatologie, Paléontologie Humaine: Evolution et Paléoenvironnements, Université de Poitiers, Poitiers, France 
Pierre-Henri Fabre

Harvard Museum of Comparative Zoology, Cambridge, MA, USA

\section{Madeleine Geiger}

Paläontologisches Institut und Museum, University of Zürich, Zürich, Switzerland

\section{Helder Gomes Rodrigues}

Institut des Sciences de l'Évolution de Montpellier, Universite Montpellier 2, Montpellier, France

\section{Franck Guy}

Institut de Paléoprimatologie, Paléontologie Humaine: Evolution et Paléoenvironnements, Université de Poitiers, Poitiers, France

\section{Lionel Hautier}

Institut des Sciences de l'Évolution de Montpellier, Université de Montpellier 2, Montpellier, France

\section{Nathan Jeffery}

Department of Musculoskeletal Biology, Institute of Ageing and Chronic Disease, University of Liverpool, Liverpool, UK

\section{Vincent Lazzari}

Institut de Paléoprimatologie, Paléontologie Humaine: Evolution et Paléoenvironnements, Université de Poitiers, Poitiers, France

\section{Renaud Lebrun}

Institut des Sciences de l'Évolution de Montpellier, Universite Montpellier 2, Montpellier, France

\section{Laurent Marivaux}

Institut des Sciences de l'Évolution de Montpellier, Universite Montpellier 2, Montpellier, France

\section{Matthew J. Mason}

Department of Physiology, Development and Neuroscience, University of Cambridge, Cambridge, UK

\section{John M. Mercer}

Biology Department, Duke University, Durham, NC, USA

\section{Jacques Michaux}

Ecole Pratique des Hautes Etudes et Institut des Sciences de l'Évolution de Montpellier, Universite Montpellier 2, Montpellier, France

Johan R. Michaux

Institut de Botanique, Université de Liège, Liège, Belgium 


\section{Sophie Montuire}

Laboratoire Paléobiodiversité et Evolution de Ecole Pratique des Hautes Etudes, Université de Bourgogne, Dijon, France

\section{Cecilia C. Morgan}

Sección Mastozoología, Museo de La Plata, La Plata, Argentina

A. Itatí Olivares

Sección Mastozoología, Museo de La Plata, La Plata, Argentina

\section{P. David Polly}

Department of Geological Science, Biology and Anthropology, Indiana University, Bloomington, IN, USA

\section{Jean-Pierre Quéré}

Centre de Biologie et Gestion des Populations, Campus International de Baillarguet Montferrier-sur-Lez, France

\section{Sabrina Renaud}

Laboratoire de Biométrie et Biologie Evolutive, Université Lyon I, Villeurbanne, France

\section{Elodie Renvoisé}

Evolutionary and Developmental Biology Laboratory, Institute of Biotechnology, University of Helsinki, Helsinki, Finland

\section{Andrés Rinderknecht}

Museo Nacional de Historia Natural, Montevideo, Uruguay

\section{Louise Roth}

Biology Department, Duke University, Durham, NC, USA

\section{Pierre-Emmanuel Salais}

Institut de Paléoprimatologie, Paléontologie Humaine: Evolution et Paléoenvironnements, Université de Poitiers, Poitiers, France

\section{Scott Steppan}

Department of Biological Science, Florida State University, Tallahassee, FL, USA

\section{Paul Tafforeau}

European Synchrotron Radiation Facility, Grenoble, France

\section{Diego H. Verzi}

Sección Mastozoología, Museo de La Plata, La Plata, Argentina

\section{Monique Vianey-Liaud}

Institut des Sciences de l'Évolution de Montpellier, Universite Montpellier 2, Montpellier, France 


\section{Laurent Viriot}

Institut de Génomique Fonctionnelle de Lyon, Ecole Normale Supérieure de Lyon, Lyon, France

\section{Laura A. B. Wilson}

School of Biological, Earth and Environmental Sciences, University of New South Wales, Sydney, Australia

\section{Alisa Winkler}

Department of Geological Sciences, Southern Methodist University, Dallas, TX, USA 


\section{Foreword}

Because it reflects the volume Evolutionary Relationships among Rodents: A Multidisciplinary Approach that we edited in 1985, nearly 30 years ago, it is a great pleasure for us to introduce this new book, which updates many of the same topics and introduces new approaches, especially in the area of functional morphology.

Our publication followed a meeting held in Paris in the spring of 1984 , with about 50 participants coming from different disciplines and countries, but all interested in the palaeontology, biology and evolutionary relationships of families from the orders Rodentia and Lagomorpha. ${ }^{\mathrm{I}}$ It was a very friendly meeting, with four days in Paris at the Centre National de la Recherche Scientifique, on the banks of the Seine and its nearby bistrots, allowing extensive scientific exchanges. Unfortunately, some Eastern colleagues could not join us for obscure political reasons: N. N. Vorontsov was not allowed to leave Moscow for a few days; the same was true for D. Dashzeveg from Oulan Bator. Fortunately, exchanges between international scientists are much easier today.

Our book was dedicated to two leading authorities on the subject at the time: René Lavocat (1909-2007) and Albert Elmer Wood (1910-2002). The book has received good success, even though it was highly priced, despite the fact that WPL and JLH did most of the editing work including the 'camera ready' mise en page; the publishers also had received some financial support from NATO (North Atlantic Treaty Organisation).

Two main topics for challenge and discussion were the Glires concept, which was at this time an open question, and the relationships of African rodents with their possible relatives in South America. Also, for some families, a documented review was proposed by different specialists, with the notable exception of the murids.

It must be added that, at the time, relationships and communications between palaeontologists and other biologists were poor: a type of reciprocal ignorance between the two communities was the rule. Thus, the meeting contributed notably to breaching the barrier between fossil specialists and those biologists studying the living world.

${ }^{\mathrm{I}}$ List of participants and authors in the 1984 Paris meeting: Jaap Beintema, François Bonhomme, Gehrard Braunitzer, Jorgen Bugge, Percy M. Butler, Ernesto Capanna, Jean Chaline, Brigitte Coiffait, John Czelusniak, Wilfried De Jong, Christiane Denys, Volker Fahlbusch, Lawrence J. Flynn, Wilma George, Morris Goodman, Jean-Louis Hartenberger, John Hermanson, Djoko Iskandar, Louis Jacobs, Jean-Jacques Jaeger, Wighart von Koenigswald, René Lavocat, Li Chuan Kuei, Everett Lindsay, W. Patrick Luckett, Nieves Lopez Martinez, Jacques Michaux, Michael Novacek, Jean-Pierre Parent, Francis Petter, Ashok Sahni, Vincent Sarich, Jehesle Shoshani, Frederick Szalay, Louis Thaler, Si Yin Ting, Monique Vianey-Liaud, John Wahlert, Albert E. Wood, and Charles Woods. 
Studies of genetics and molecular phylogeny were still in the early stages: techniques allowing exploitation of the molecular clock concept (1965) had only recently been solved.

One of the main results of the meeting was that the Glires concept of a sister-group relationship between Rodentia and Lagomorpha received good support from both paleontologists and some neontologists. However, four contributions from molecular biologists in the book provided no support for the Glires hypothesis, even though most did not directly address the subject. These studies dealt with analyses of amino acids or immunological distance data from only a few groups of rodents. Nevertheless, one author (Vincent Sarich) boldly asserted that 'I know of no molecular data which would suggest any rodent-lagomorph affinities, and there are appreciable, if not sufficient, data to in fact reject the rodent-lagomorph hypothesis'. Molecular phylogenetic studies were still in early development, with little analysis of nucleotide data, and other authors were less provocative and more open to discussion. Subsequent studies of molecular evolution in rodents during recent decades, with greater emphasis on increased taxon sampling, as well as newer methods of analysing nuclear protein-coding genes, have resulted in near-uniform support for the monophyly of Glires.

At present, the Glires concept is stronger than ever. Thanks first to the very significant discoveries and interpretations concerning Palaeocene Mongolian and Chinese primitive lagomorphs and rodents. In addition, newer techniques in molecular studies and analyses have been developed, and Pierre-Henri Fabre and his colleagues give here a refreshing mise au point concerning the molecular phylogeny of Rodentia. In some ways their conclusions are in total agreement with recent results concerning the tempo and mode of placental mammal radiations. It is now demonstrated that the radiation of Glires, as the emergence of all modern orders of mammals, is a postCretaceous/Palaeogene event. Extending these results about the origins of Rodentia, Mary Dawson gives an overview concerning the question: what really is a primitive rodent?

Concerning possible relationships between African and South American rodents, the monophyly of Hystricognathi has now received nearly universal support from both palaeontologists and neontologists. At the time of the Paris meeting, the importance of the Ctenodactylidae was emerging, and some participants were convinced that African Hystricognathi could be rooted in the Asian early Eocene Ctenodactyloidea. Indeed, in our summary of the conference, we presented as a working hypothesis the possible sister-group relationship between Hystricognathi and Ctenodactyloidea. This hypothesis subsequently received strong support from molecular analyses, and resulted in the naming of a new higher taxon Ctenohystrica. This hypothesis also reflects the importance of Tethys sea margins for biogeographical exchanges. This allowed East-West faunal exchanges on both sides of Tethys from Eastern Asia to Africa, Europe and America. Not only were marine mammals (Sirenia and Archeoceta) involved in these migrations, but terrestrial mammals were also involved.

In fact, what is really new from the time of the Paris congress is that new methods and tools have opened new perspectives and approaches for students in evolutionary biology. 
The building of phylogenetic trees using molecular and morphological data are now codified, so that matrices of characters are always open to discussion and modification in a way that all workers are aware of modifications; these data are available in Morphobank and Genbank. Also digital libraries have opened new perspectives. Many of these are highly priced, but they generate new facilities for workers, and we older investigators must confess that we are in some ways a little envious regarding our younger colleagues.

For morphological observations, there has been a numerical revolution since the end of the century: scanners, ${ }_{3} \mathrm{D}$, digimorph studies, high-resolution $\mathrm{X}$-ray computed tomography and tomo-densitometry techniques provide spectacular imagery and animations for rare fragile fossil or living specimens. Thus, morphological data are more acute and, in some cases, developmental and embryological studies provide new windows for evolutionary studies. The counterpart of this is that there are almost too many publications and papers. The 'publish or perish' constraint seems too high. Also, it could be noted that there are too many multi-authored papers, but this is also the consequence of the use of sophisticated techniques and must be considered a necessity.

We hope the new book will invite younger students to study more aspects of rodent biology and evolution; with more than 2000 species, the order needs more attention than any other, including ours!

JEAN-LOUIS HARTENBERGER

and

W. PATRICK LUCKETT 


\title{
19
}

\section{Diversity and evolution of femoral variation in Ctenohystrica}

\author{
LAURA A.B. WILSON AND MADELEINE GEIGER
}

\section{Introduction}

Despite possessing a rather generalized postcranial skeleton, rodents are on average capable of a wide variety of locomotory behaviours, such as swimming, digging and climbing (Nowak, 1999). Particularly, rodents belonging to Ctenohystrica (sensu Huchon et al., 2002, and Fabre et al., 2012: Ctenodactylidae, Diatomyidae and Hystricognathi) display a diversity of locomotory styles and encompass a large range in body mass from approximately $50 \mathrm{~g}$ for the naked mole-rat Heterocephalus glaber to around $60 \mathrm{~kg}$ for the largest living rodent, the capybara Hydrochoeris hydrochaeris, consequently filling many different ecological niches (e.g. MacDonald, 2009; Wilson and Sánchez-Villagra, 2009, 2010). Moreover, this diversity is greatly expanded by the inclusion of giant extinct members such as Phoberomys, Arazamys and Josephoartigasia that reached body masses at least seven or eight times that of the capybara (SánchezVillagra et al., 2003, Rinderknecht and Blanco, 2008; Rinderknecht and Bostelmann, 20II). The adaptive diversity that characterizes the evolution of Ctenohystrica, and particularly the Caviomorpha, a group that dispersed from Africa to colonise South America (Poux et al., 2006; Rowe et al., 2010) and evolved on that continent during a period of splendid isolation in the Cenozoic, has been the subject of numerous morphofunctional and evolutionary studies (e.g. Verzi et al., 20Io; Wilson et al., 20Iо; Álvarez et al., 20IIa, b; Hautier et al., 20II, 20I2; Cox et al., 20I2; Geiger et al., 20I3; Wilson, 2013).

The interplay between form and function has been studied in the postcranial skeleton of a number of mammals (e.g. Kappelman, I988; Anemone, I990; White, I993; Vizcaíno and Milne, 2002; Kley and Kearney, 2007; Meachen-Samuels, 2010), and studies of Ctenohystrica have, for example, examined individual bones (e.g. Seckel and Janis, 2008; Morgan, 2009; Steiner-Souza et al., 2010; Elissamburu and De Santis, 20II), long bones (Biknevicius, 1993; Elissamburu and Vizcaino, 2004; Samuels and Van Valkenburgh, 2008; Morgan and Álvarez, 2013) and the autopodial skeleton (e.g. Weisbecker and Schmid, 2007; Morgan and Verzi, 20II). These studies have used morphological traits, described as ratios or quantified using biomechanical indices or geometric morphometric descriptors of shape, to identify functional specializations and instances of adaptive convergence underpinned by shared function and/or ecology. A large body 
of evidence supports the functional information content of the postcranial skeleton, and ecological and locomotor habit signal extracted from analyses of extant species has successfully been used to help reconstruct the palaeobiology of extinct species (e.g. Van Valkenburgh, 1987; Argot, 200I, 2004; Lessa et al., 2008; Samuels and Van Valkenburgh, 2008; Geiger et al., 2013; Samuels et al., 2013). Functional indices of the femora have been found to be among the best predictors of locomotory habit, reflecting the relationship between force and speed variation in the hindlimbs, and enabling cursorial and digging rodents to be distinguished (Elissamburu and Vizcaíno, 2004). Nevertheless, a wide range of functional indices that cover most anatomical structures of the femur has not been developed and investigated across members of Ctenohystrica, which limits our understanding of the amount and pattern of femoral variation that has evolved in this anatomically diverse group.

In this study, a range of morphological parameters, corresponding to diameters and functional lengths, including lengths between articular surfaces and muscle attachment points, of femora in a wide sample of species belonging to Ctenohystrica were measured. The indices built from these measurements are used to investigate the biomechanical properties and variability of femoral morphology among members of locomotor groups present within Ctenohystrica.

\section{The mammalian femur}

The terms introduced here will be used throughout this study, and the following descriptions are based on previous works by Voss and Herrlinger (1975), Starck (1979), Scheuer and Black (2000), Schünke (2000), Turvey et al. (2006), Polly (2007), and Schaller (2007). The most important features of the bone are discussed, and these are illustrated in Figure I9.I.

The femur among mammals is very uniformly shaped. The bone is usually long, slender, and has a rounded cross section. Its proximal part - the spherical shaped femoral head - is articulated with the acetabulum of the pelvis. It is connected with the femoral shaft (diaphysis) in an oblique angle through the femoral neck. Some of the most prominent muscle attachment points on the femur are the greater trochanter, the lesser trochanter, and the third trochanter. The greater trochanter is a proximal extremity, lateral to the femoral head, whereas the lesser trochanter lies on the medial side of the femur, right under the base of the femoral neck. The third trochanter - if present - is situated on the lateral side of the bone but is very variable in its size and position along the shaft. On the dorsal side of the proximal femur, the intertrochanteric crest runs from the greater trochanter distally, in some cases reaching the lesser trochanter. The medial side of the caudal aspect of the greater trochanter together with the intertrochanteric crest define a deep notch, the trochanteric fossa. On the distal end of the femoral shaft, the bone becomes thicker and there are two convexities the condyles - that are angled caudally, and together build the articular surfaces that are connected with the tibia. The elevations on the lateral and the medial condyles are termed the lateral and medial epicondyles, respectively. The region in between the 


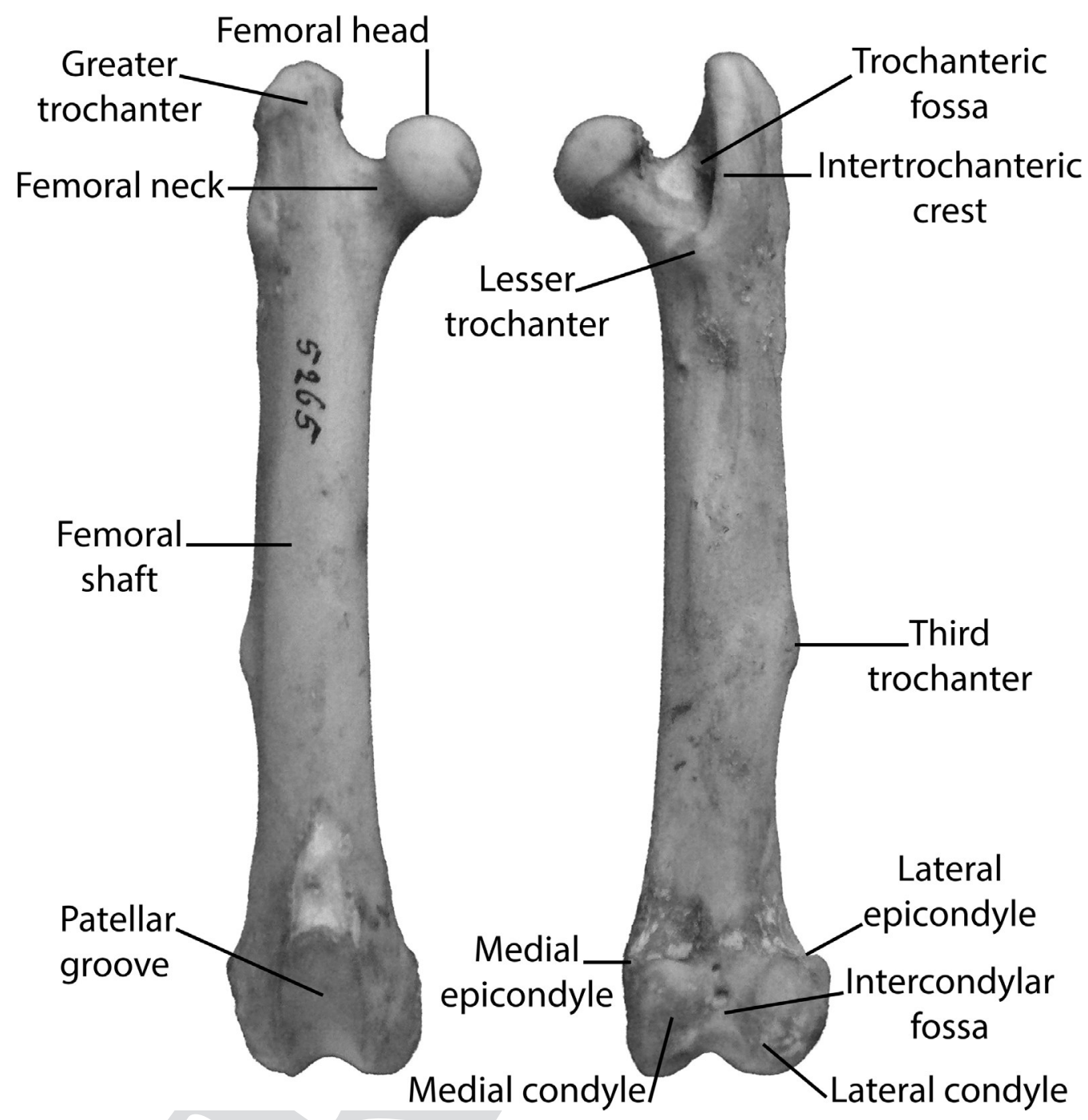

Figure 19.I Right femur of the caviomorph Dasyprocta azarae (NMB 5265) with indicated femoral morphological features. Left: anterior aspect; right: posterior aspect.

condyles is referred to as the patellar groove on the cranial surface, and is termed the intercondylar fossa on the caudal surface.

\section{Functional adaptations and locomotion}

Among mammals, functional adaptations of the femur affect mainly (I) the length and orientation of the greater trochanter; (2) the size of the third trochanter; (3) the shape of the femoral head; and (4) the depth of the patellar groove (Polly, 2007) (Figure 19.I). Rodent femora can be distinguished from those of other mammals using morphological differences in the shape of the femoral head and the relative breadth of the head in relation to the femoral neck. Compared to marsupials, euungulates, bats, 
carnivorans and non-hominoid primates, rodents have a longer, more constricted and well-defined femoral neck. Secondary ossification centres for the femoral head and greater trochanter also remain distinct throughout growth in rodents and, along with a constricted femoral neck, may reflect the increased need for hip mobility, associated with a more complex repertoire of limb movement (Serrat et al., 2007).

The members of Ctenohystrica studied herein can be placed in six groups based on behavioural and morphological features (after Polly, 2007; Samuels and Van Valkenburgh, 2008). (I) Cursorial mammals have adaptations that allow greater running speeds. (2) Terrestrial (synonyms: generalised or ambulatory) mammals do not have obvious specialisations for any particular locomotor style. Walking, running, climbing, swimming, digging and manipulating objects are possible for these mammals because they do not have skeletal specializations that limit these activities, though none is performed extensively. (3) Scansorial mammals are generally well adapted for climbing and are capable of and regularly seen climbing for escape, shelter or foraging. (4) Arboreal mammals live in trees all of their life, not only for escape, shelter or foraging. (5) Semi-aquatic mammals regularly swim for dispersal, escape, or foraging. They show specialisations to a life in aquatic environments while maintaining the ability to disperse across or acquire food on land. (6) Fossorial mammals regularly dig to build extensive burrows for foraging or shelter. The definitions for arboreal and scansorial are overlapping but among the caviomorph clade, obligate climbers, i.e. arboreal species (e.g. Coendou prehensilis), can be clearly distinguished from species that are simply able and frequent climbers, i.e. scansorial species (e.g. Octodon degus). We here also investigate a fossil femur from a giant caviomorph rodent (NMB SA-259) (Horovitz et al., 20Io; Geiger et al., 2013) from the Late Miocene deposits of the Springvale Beds (Caroni County, Trinidad) (Kugler, 20oI) in order to deduce its yet not known mode of locomotion. NMB SA-259 was first reported by Schaub (1935), and the Springvale Beds in which the specimen was located have been stratigraphically related with the Codore series of the Urumaco area in Venezuela (Kugler, 20or), which has yielded remains of numerous giant rodents (Sánchez-Villagra et al., 2003; Horovitz et al., 2006, 2010)

\section{Methods}

\section{Specimens, locomotor types and body mass}

A total of 78 Ctenohystrica specimens were examined, including I fossil caviomorph (NMB SA-259, cf. Phoberomys sp.; Geiger et al., 2013), and comprising 35 extant species (Table I9.I). Captive and wild caught specimens of both sexes were used because there is very little sex-based size, and therefore most probably morphological, dimorphism in extant caviomorphs (Biknevicius, 1993). Either the left or the right femur was chosen in order of availability and preservation quality. Data were compiled on body mass from Nowak (1999) and the panTHERIA database by Jones et al. (2009), and on locomotor type from Nowak (1999), Elissamburu and Vizcaíno 
Table 19.I List of investigated species (scientific species names follow contributions in Wilson and Reeder, 2005) with number of specimens examined $(n)$; species mean body mass in grams and corresponding locomotory type. Information about body mass was obtained from Nowak (1999) and panTHERIA database by Jones et al. (2009). Information about locomotor types was obtained from Nowak (1999), Elissamburu and Vizcaíno (2004), Weisbecker and Schmid (2007), Samuels and Valkenburgh (2008), IUCN Red List, and the Palaeobiology Database.

\begin{tabular}{|c|c|c|c|c|c|}
\hline Taxa & $\begin{array}{l}\text { Scientific species } \\
\text { name }\end{array}$ & $\begin{array}{l}\text { Popular species } \\
\text { name }\end{array}$ & $n$ & $\begin{array}{l}\text { Body } \\
\text { mass }(g)\end{array}$ & $\begin{array}{l}\text { Locomotor } \\
\text { type }\end{array}$ \\
\hline \multicolumn{6}{|l|}{ Caviomorpha } \\
\hline \multirow[t]{3}{*}{ Caviidae } & Cavia porcellus & $\begin{array}{c}\text { Domesticated } \\
\text { guinea pig }\end{array}$ & 2 & $727 \cdot 99$ & terrestrial \\
\hline & $\begin{array}{l}\text { Dolichotis } \\
\text { patagonum }\end{array}$ & $\begin{array}{l}\text { Patagonian hare } \\
\text { (mara) }\end{array}$ & 7 & 8000 & cursorial \\
\hline & Galea musteloides & $\begin{array}{l}\text { Common yellow- } \\
\text { toothed cavy }\end{array}$ & I & 386.64 & terrestrial \\
\hline \multirow[t]{4}{*}{ Chinchillidae } & $\begin{array}{l}\text { Chinchilla } \\
\text { lanigera }\end{array}$ & $\begin{array}{l}\text { Long-tailed } \\
\text { chinchilla }\end{array}$ & 5 & 480.28 & scansorial \\
\hline & Chinchilla sp. & & & & \\
\hline & $\begin{array}{l}\text { Lagidium } \\
\text { peruanum }\end{array}$ & $\begin{array}{l}\text { Northern } \\
\text { mountain } \\
\text { viscacha }\end{array}$ & I & $\mathrm{I} 22 \mathrm{O}$ & scansorial \\
\hline & $\begin{array}{l}\text { Lagostomus } \\
\text { maximus }\end{array}$ & Plains viscacha & 4 & 4660.94 & terrestrial \\
\hline Ctenomyidae & $\begin{array}{l}\text { Ctenomys } \\
\quad \text { brasiliensis }\end{array}$ & Brazilian tuco-tuco & I & 400 & fossorial \\
\hline Cuniculidae & Cuniculus paca & Spotted paca & 3 & $8 \mathrm{I} 72.55$ & terrestrial \\
\hline \multirow[t]{2}{*}{ Dasyproctidae } & Dasyprocta & Brazilian agouti & 9 & 3009.99 & cursorial \\
\hline & $\begin{array}{l}\text { leporina } \\
\text { Myoprocta pratti }\end{array}$ & Green acouchi & 3 & 966.73 & cursorial \\
\hline Dinomyidae & $\begin{array}{l}\text { Dinomys } \\
\text { branickii }\end{array}$ & Pacarana & I & $\mathrm{I} 2500$ & scansorial \\
\hline \multirow[t]{3}{*}{ Echimyidae } & Clyomys laticeps & $\begin{array}{l}\text { Broad-headed } \\
\text { spiny rat }\end{array}$ & I & $20 \mathrm{I}$ & fossorial \\
\hline & $\begin{array}{c}\text { Kannabateomys } \\
\text { amblyonyx }\end{array}$ & $\begin{array}{l}\text { Atlantic bamboo } \\
\text { rat }\end{array}$ & I & 599.99 & arboreal \\
\hline & $\begin{array}{l}\text { Proechimys } \\
\text { guyannensis }\end{array}$ & Cayenne spiny rat & 2 & $3 \mathrm{I} 4.03$ & terrestrial \\
\hline \multirow[t]{4}{*}{ Erethizontidae } & $\begin{array}{l}\text { Chaetomys } \\
\text { subspinosus }\end{array}$ & $\begin{array}{l}\text { Thin-spined } \\
\text { porcupine }\end{array}$ & I & I299.99 & arboreal \\
\hline & $\begin{array}{l}\text { Coendou } \\
\text { prehensilis }\end{array}$ & $\begin{array}{l}\text { Brazilian } \\
\text { porcupine }\end{array}$ & 3 & $4 \mathrm{II} 6.2$ & arboreal \\
\hline & Erethizon dorsata & $\begin{array}{l}\text { North American } \\
\text { porcupine }\end{array}$ & 3 & $7419 \cdot 46$ & scansorial \\
\hline & $\begin{array}{l}\text { Sphiggurus } \\
\text { spinosus }\end{array}$ & $\begin{array}{l}\text { Paraguay hairy } \\
\text { dwarf porcupine }\end{array}$ & I & 750.78 & arboreal \\
\hline
\end{tabular}


Table I9.I (cont.)

\begin{tabular}{|c|c|c|c|c|c|}
\hline Taxa & $\begin{array}{l}\text { Scientific species } \\
\text { name }\end{array}$ & $\begin{array}{l}\text { Popular species } \\
\text { name }\end{array}$ & $n$ & $\begin{array}{l}\text { Body } \\
\text { mass (g) }\end{array}$ & $\begin{array}{l}\text { Locomotor } \\
\text { type }\end{array}$ \\
\hline Hydrochaeridae & $\begin{array}{l}\text { Hydrochoeris } \\
\text { hydrochaeris }\end{array}$ & Capybara & 3 & $48 \mathrm{I} 44 \cdot 9 \mathrm{I}$ & $\begin{array}{l}\text { semi- } \\
\text { aquatic }\end{array}$ \\
\hline Myocastroidae & Myocastor coypus & Nutria & 3 & $636 \mathrm{I} .55$ & semi- \\
\hline Octodontidae & $\begin{array}{l}\text { Octodon degus } \\
\text { Octodon sp. }\end{array}$ & Degu & $\begin{array}{l}2 \\
I\end{array}$ & 203.27 & scansorial \\
\hline Neoepiblemidae & cf. Phoberomys sp. & & I & 391187 & unknown \\
\hline \multicolumn{6}{|l|}{ Phiomorpha } \\
\hline \multirow[t]{3}{*}{ Bathyergidae } & Bathyergus suillus & $\begin{array}{l}\text { Cape dune mole } \\
\text { rat }\end{array}$ & I & $777 \cdot 38$ & fossorial \\
\hline & $\begin{array}{l}\text { Cryptomys } \\
\text { hottentotus }\end{array}$ & African mole rat & I & $75 \cdot 13$ & fossorial \\
\hline & $\begin{array}{l}\text { Georychus } \\
\text { capensis }\end{array}$ & Cape mole rat & 2 & 188.36 & fossorial \\
\hline \multirow[t]{4}{*}{ Hystricidae } & $\begin{array}{l}\text { Atherurus } \\
\text { africanus }\end{array}$ & $\begin{array}{l}\text { African brush- } \\
\text { tailed porcupine }\end{array}$ & I & 2875.65 & terrestrial \\
\hline & Hystrix cristata & Crested porcupine & 2 & $\mathrm{I} 3406.27$ & terrestrial \\
\hline & Hystrix indica & $\begin{array}{l}\text { Indian crested } \\
\text { porcupine }\end{array}$ & I & $\mathrm{I} 4298.6$ & terrestrial \\
\hline & Hystrix sp. & & I & & \\
\hline \multirow[t]{2}{*}{ Thryonomyidae } & $\begin{array}{l}\text { Thryonomys } \\
\text { gregorianus }\end{array}$ & Lesser cane rat & I & 2707.14 & terrestrial \\
\hline & $\begin{array}{l}\text { Thryonomys } \\
\text { swinderianus }\end{array}$ & Greater cane rat & 2 & 3750.85 & $\begin{array}{l}\text { semi- } \\
\text { aquatic }\end{array}$ \\
\hline \multicolumn{6}{|c|}{ Ctenodactylomorphi } \\
\hline \multirow[t]{3}{*}{ Ctenodactylidae } & Ctenodactylus vali & Val's gundi & 2 & I73.6 & terrestrial \\
\hline & $\begin{array}{l}\text { Massoutiera } \\
\text { mzabi }\end{array}$ & Mzab gundi & 2 & I94 & terrestrial \\
\hline & Pectinator spekei & Speke's pectinator & 2 & I69.7 & terrestrial \\
\hline
\end{tabular}

(2004), Weisbecker and Schmid (2007), Samuels and Valkenburgh (2008) and the IUCN Red List (20II). The locomotor type of the fossil NMB SA-259 was defined as 'unknown', and its body mass was calculated as the mean of values resulting from body mass estimation calculations performed by Geiger et al. (2013) using three different methods. The specimens measured in the study are housed at the Naturhistorisches Museum Basel, Switzerland (NMB); Zoologisches Museum Zürich, Switzerland (ZMUZH); Naturhistorisches Museum Bern, Switzerland (NMBE); and The Natural History Museum London, UK (NHM).

Although there were almost no visible differences in femoral morphology between adults and subadults, differences in morphology through ontogeny could not be 
excluded entirely. Therefore only adult specimens, defined as having the femoral epiphyses at the femoral head, the greater trochanter, the lesser trochanter, and the distal femoral condyles fused (with epiphyseal line either visible or absent), were used for analyses, and follow stages 3 and 4 of Walker's (1987) epiphyseal fusion sequence. A total of 59 to 74 adult specimens remained for analysis of the 17 indices, described below, that were developed to quantify femoral morphology. For further analyses of the femoral indices, species' means were constructed ( 26 to 3 I species).

\section{Measurements and indices}

In sum, 33 measurements were recorded on each femur, partly based on previous works of Abderhalden (1938), McHenry and Corruccini (1978), Knussmann (1980), Hermann et al. (1990), Buikstra and Ubelaker (1994), and Harmon (2006). All measurements were recorded to the nearest $0.0 \mathrm{~cm}$ using callipers. Nineteen of the 33 measurements were used to compute functional indices (Table I9.2 Nos. I-I9, Figure 19.2), and the remaining I4 measurements were used to supplement the analyses based on indices by providing additional information on variability in femoral morphology (Table 19.2 Nos. 20-33, Figure 19.3). Functional indices were computed for the proximal and distal portions of the femur and the diaphyses, and were chosen to represent overall limb proportions and mechanical advantages of the principal muscles related to limb function and locomotion (Table 19.3). Some indices were developed from previous studies (Kappelman, I988; Anemone, I990; Elissamburu and Vizcaíno 2004; Samuels and Van Valkenburgh, 2008). In addition, after examination of the study specimens, some novel indices were created to capture differences in features among the investigated locomotor groups. In total, three data sets were constructed: (I) raw measurements of the femur for all specimens, $(2)$ functional indices $(N=\mathrm{I} 7)$ computed for all specimens, and (3) functional indices computed for species' means.

\section{Statistical analyses and ordination methods}

Because some of the differences in femoral morphology may result simply from allometrically related scaling differences, all measures and indices were corrected for body size before statistical analyses were conducted. Standard least square regressions of $\log _{\text {IO }}$ measurements and indices with $\log _{\text {Io }}$ species means of body masses were conducted, and the resulting residuals were used for further analyses.

Differences between species means for each locomotor group were assessed using one-way ANOVAs coupled with posthoc Tukey-Kramer HSD tests. For each of the three data sets (raw measurements, functional indices for all specimens and functional indices for species' means) these tests were conducted on all sampled representatives from Ctenohystrica (Caviomorpha, Phiomorpha and Ctenodactylidae).

The influence of numerator and denominator on each of the indices was assessed, as differences in numerator, denominator or both may result in a similar index value for functionally distinct forms (see Samuels and Van Valkenberg, 2008). Therefore, the 
Table 19.2 Osteological measurements used to compute functional indices.

\begin{tabular}{|c|c|c|}
\hline & Measurement & Description \\
\hline $\mathbf{I}$ & Bicondylar length & $\begin{array}{l}\text { Distance from the most superior point on the femoral head to a } \\
\text { plane drawn along the inferior surfaces of the distal condyles. }\end{array}$ \\
\hline 2 & Proximal width & $\begin{array}{l}\text { Distance from the most medial point on the femoral } \\
\text { head to the most lateral point of the greater trochanter. }\end{array}$ \\
\hline 3 & $\begin{array}{l}\text { Head-trochanter } \\
\text { distance }\end{array}$ & $\begin{array}{l}\text { Distance from the most superior point of the femoral head to the } \\
\text { most inferior point of the lesser trochanter. }\end{array}$ \\
\hline 4 & Trochanteric distance & $\begin{array}{l}\text { Distance from the most superior point of the greater trochanter to } \\
\text { the most inferior point of the lesser trochanter. }\end{array}$ \\
\hline 5 & $\begin{array}{l}\text { Greater trochanter } \\
\text { length }\end{array}$ & $\begin{array}{l}\text { Distance from the most superior point of the greater trochanter to } \\
\text { the elongated neck axis on the lateral border of the femur. }\end{array}$ \\
\hline 6 & $\begin{array}{l}\text { Transversal head } \\
\text { diameter }\end{array}$ & $\begin{array}{l}\text { Distance between the two most laterally projecting points of the } \\
\text { femoral head, perpendicular to the vertical head diameter. }\end{array}$ \\
\hline 7 & $\begin{array}{l}\text { Vertical head } \\
\text { diameter }\end{array}$ & $\begin{array}{l}\text { Distance between the most superior to the most inferior point of } \\
\text { the femoral head, perpendicular to the transversal head } \\
\text { diameter. }\end{array}$ \\
\hline
\end{tabular}

8 Vertical neck diameter Smallest distance of the upper border to the lesser border of the neck, perpendicular to the anterior-posterior diameter of the neck.

9 Anterioposterior neck Distance from the anterior border to the posterior border of the diameter neck, perpendicular to the vertical diameter of the neck.

Io Lesser trochanter length

Maximum superior-inferior length defined by the margin of the eminence.

II Lesser trochanter breadth

Maximum mediolateral breadth defined by the margin of the eminence.

I2 Proximal mediolateral Distance between medial and lateral surfaces of the proximal end (transverse) subtrochanteric shaft diameter

13 Anteriorposterior (saggital) subtrochanteric of the diaphysis below the base of the lesser trochanter, perpendicular to the proximal anteroposterior subtrochanteric diameter. shaft diameter

Distance between anterior and posterior surfaces measured approximately at the midpoint of the diaphysis, perpendicular to the mediolateral midshaft diameter.

I4 Mediolateral (transverse) midshaft diameter

I5 Anteroposterior (saggital) midshaft diameter

Distance between the medial and lateral surfaces at midshaft, perpendicular to the anterior-posterior diameter.

Distance between anterior and posterior surfaces measured approximately at the midpoint of the diaphysis, perpendicular to the mediolateral midshaft diameter.

I6 Anteroposterior diameter of the distal shaft

Anteroposterior diameter of the shaft at the distal end excluding the distal epiphysis.

I7 Bicondylar width

Maximum transverse (mediolateral) diameter of the distal end, perpendicular to the diaphysis. 
Table I9.2 (cont.)

\begin{tabular}{|c|c|c|}
\hline & Measurement & Description \\
\hline 18 & $\begin{array}{l}\text { Thickness } \\
\text { (anteroposterior } \\
\text { diameter) of the } \\
\text { medial condyle }\end{array}$ & $\begin{array}{l}\text { Distance of the most anterior point of the medial condyle to a } \\
\text { plane along the posterior surfaces of both condyles, } \\
\text { perpendicular to the shaft. }\end{array}$ \\
\hline I9 & $\begin{array}{l}\text { Thickness } \\
\text { (anteroposterior } \\
\text { diameter) of the } \\
\text { lateral condyle }\end{array}$ & $\begin{array}{l}\text { Distance of the most anterior point of the lateral condyle to a } \\
\text { plane along the posterior surfaces of both condyles, } \\
\text { perpendicular to the shaft. }\end{array}$ \\
\hline 20 & Trochanter length & $\begin{array}{l}\text { Distance from the most superior point of the greater trochanter to } \\
\text { a plane drawn along the inferior surfaces of the condyles. }\end{array}$ \\
\hline $2 \mathbf{I}$ & $\begin{array}{l}\text { Greater trochanter } \\
\text { projection }\end{array}$ & $\begin{array}{l}\text { Distance between the superior most point on the greater } \\
\text { trochanter and the superior border of the neck. }\end{array}$ \\
\hline 22 & $\begin{array}{l}\text { Greater trochanter } \\
\text { protrusion }\end{array}$ & $\begin{array}{l}\text { Distance from the most medial point of the grater trochanter to } \\
\text { the most lateral point of the greater trochanter. }\end{array}$ \\
\hline 23 & $\begin{array}{l}\text { Upper epiphyseal } \\
\text { length }\end{array}$ & $\begin{array}{l}\text { Distance from the endpoint of the elongated neck axis on the head } \\
\text { surface to the endpoint of the same axis on the lateral border of } \\
\text { the femur. }\end{array}$ \\
\hline 24 & Neck length & $\begin{array}{l}\text { Distance between the head-neck border and the crista } \\
\text { intertrochanterica on the dorsal side, parallel to the neck-axis. }\end{array}$ \\
\hline 25 & $\begin{array}{l}\text { Lesser trochanter to } \\
\text { neck distance }\end{array}$ & $\begin{array}{l}\text { Minimum distance between the inferior border of the lesser } \\
\text { trochanter and the superior border of the neck. }\end{array}$ \\
\hline 26 & $\begin{array}{l}\text { Greater trochanter } \\
\text { breadth }\end{array}$ & Maximum anteroposterior breadth of the greater trochanter. \\
\hline 27 & $\begin{array}{l}\text { Transverse diameter } \\
\text { of the medial } \\
\text { condyle }\end{array}$ & $\begin{array}{l}\text { Transverse diameter of the medial condyle taken on its posterior } \\
\text { aspect, perpendicular to the diaphysis. }\end{array}$ \\
\hline 28 & $\begin{array}{l}\text { Transverse diameter } \\
\text { of the lateral } \\
\text { condyle }\end{array}$ & $\begin{array}{l}\text { Transverse diameter of the lateral condyle taken on its posterior } \\
\text { aspect, perpendicular to the diaphysis. }\end{array}$ \\
\hline 29 & Condylar notch width & $\begin{array}{l}\text { Distance from the lateral border of the medial condyle to the } \\
\text { medial border of the lateral condyle, taken at the middle of the } \\
\text { posterior aspect. }\end{array}$ \\
\hline 30 & $\begin{array}{l}\text { Width of the patellar } \\
\text { groove }\end{array}$ & Maximum width of the facies patellaris. \\
\hline $3 \mathbf{I}$ & $\begin{array}{l}\text { Collo-diaphyseal } \\
\text { angle }\end{array}$ & Angle between the diaphysis and the neck of the femur. \\
\hline 32 & $\begin{array}{l}\text { Condylo-diaphyseal } \\
\text { angle }\end{array}$ & $\begin{array}{l}\text { Angle between the diaphysis and a plane drawn along the inferior } \\
\text { surfaces of the distal condyles. }\end{array}$ \\
\hline 33 & Angle of torsion & $\begin{array}{l}\text { Angle between the head neck axis and a plane drawn along the } \\
\text { inferior surfaces of the distal condyles. }\end{array}$ \\
\hline
\end{tabular}


(a)

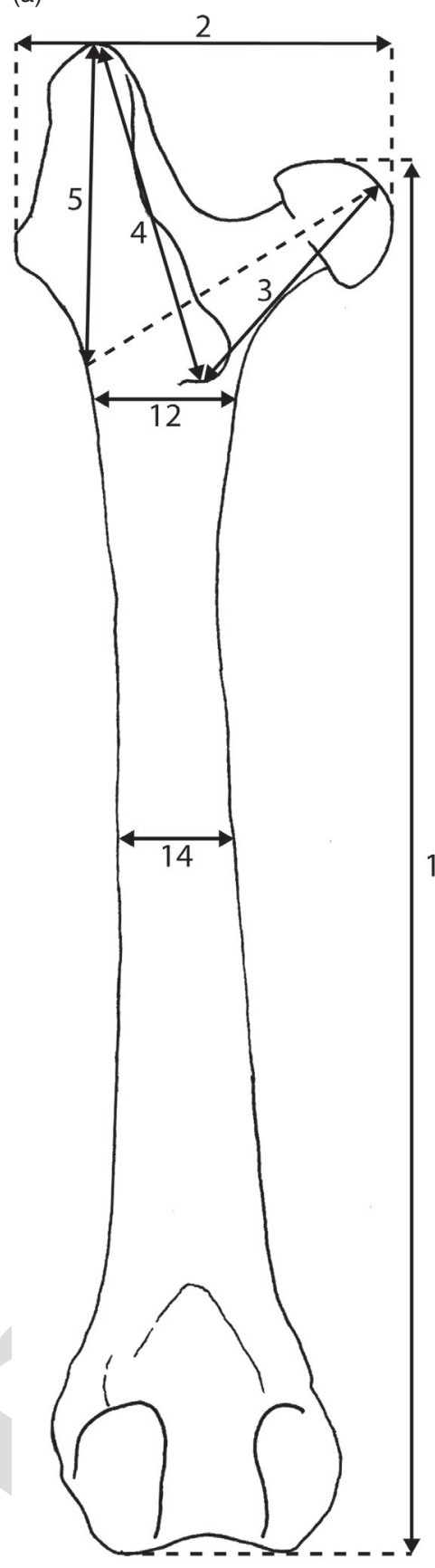

(b)

(c)

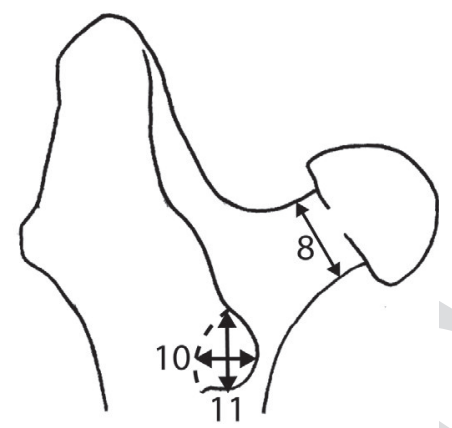

1

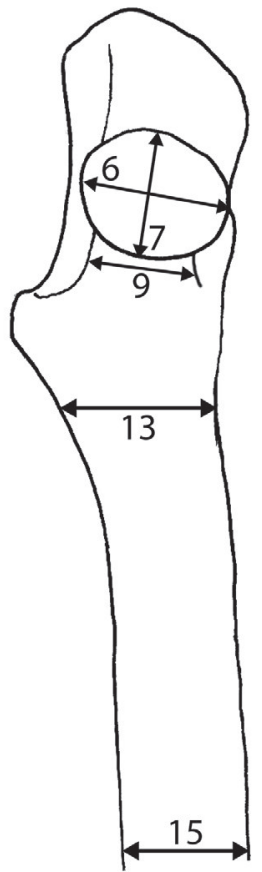

(d)

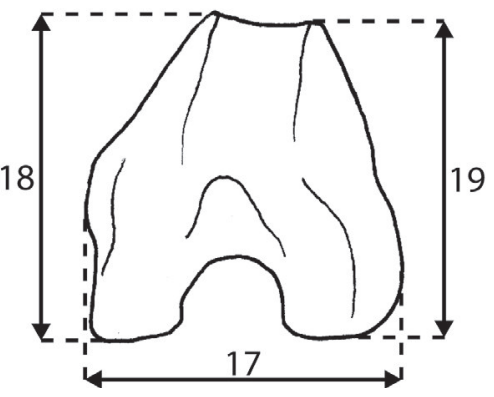

Figure 19.2 Diagram of measurements that were used to build femoral indices. Numbers refer to descriptions in the text. (a) Posterior aspect; (b) posterior aspect of the proximal femur; (c) medial aspect of the upper half of the femur; (d) inferior aspect. 
(a)

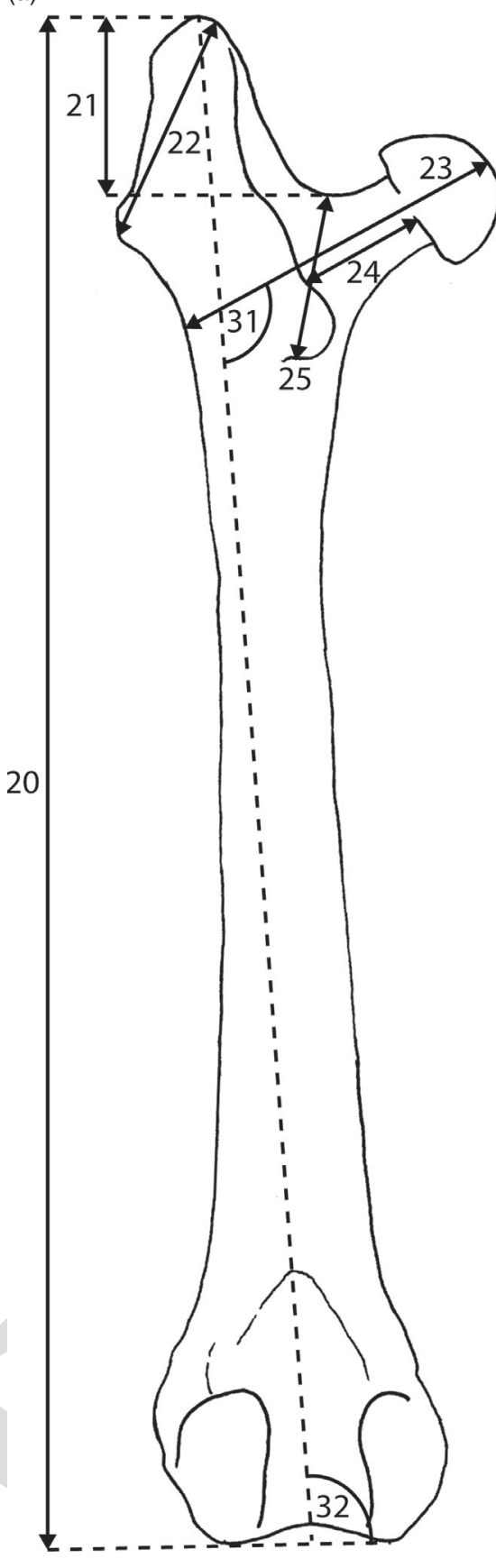

(b)

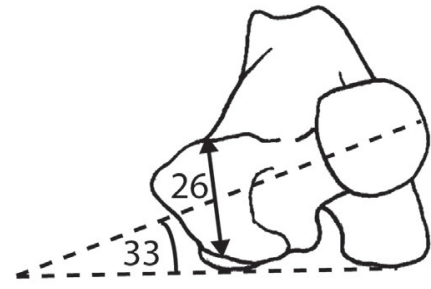

(c)

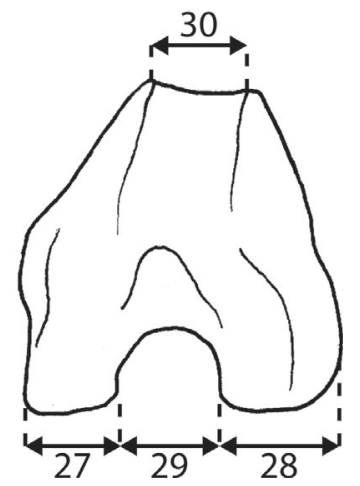

Figure 19.3 Diagrams of measurements that were used for computing the variance among locomotor groups using Principal Component Analysis. Numbers refer to descriptions in the text. (a) Posterior aspect; (b) superior aspect; (c) inferior aspect. 
Table 19.3 Definition of femoral indices calculated in this study. Explanations of functional significance are provided along with measurements (numbers in bracket refer to definitions in Table 19.2, illustrated in Figures 19.2 and 19.3) used for computation.

Proximal femur

Greater trochanter index (GTI)

Gluteal index (GI)

Head roundness (HR)

Head dimension (HD)

Femoral neck index (FNI)

Hip flexor index (HFI)

Dimensions of the lesser trochanter (DLT)

\section{Position of the lesser} trochanter (PLT)

\section{Femoral diaphyses}

Femur robustness index (FRI)
The proximal width divided by the functional length is a measure of the distance from the hip joint to the lateral edge of the greater trochanter relative to femoral length. Proximal width (2) / Bicondlyar length (I)

The proximal extension of the greater trochanter divided by the functional femoral length indicates the relative mechanical advantage of the gluteus medius muscle used in the extension of the femur. Greater trochanter length (5)/Bicondylar length (I)

The anteroposterior diameter of the femoral head divided by the mediolateral diameter of the femoral head provides an impression of roundness. Transverse head diameter (6) /

Vertical head diameter (7)

The circumference of the femoral head divided by the functional length of the femur, used to quantify dimensions of the femoral head. ([Transverse head diameter (6) + Vertical head diameter (7))/ 2]" pi) / Bicondylar length (I)

The mediolateral neck diameter divided by the anteroposterior neck diameter captures the shape of the femoral neck. Anterioposterior neck diameter (9) / Vertical neck diameter (8) The distance from the distal boarder of the lesser trochanter to the proximal border of the head divided by the functional length of the femur is a measure of the distal extent of the lesser trochanter relative to the overall femoral length. Head trochanter distance (3) / Bicondylar length (I)

The lesser trochanter breadth times the lesser trochanter length divided by the functional length is a measure of the relative size of the lesser trochanter. (Lesser trochanter breadth (II) * Lesser trochanter length (Io))/ Bicondylar length (I)

The distance between the most inferior point of the lesser trochanter and the most superior point of the femoral head divided by the distance between the most inferior point of the lesser trochanter and the most superior point of the greater trochanter. Indicates the relative position of the lesser trochanter on the shaft. Head trochanter distance (3) I Trochanteric distance (4)

Defined as the mean of the anteroposterior and mediolateral diameter of the femoral midshaft divided by the functional femoral length. Indicates robustness of the femur and its ability to resist bending and shearing stresses associated with velocity increase and is a measure of capacity to support body 
Table 19.3 (cont.)

Proximal femur

Proximal shaft ratio (PSR)

mass. ([Mediolateral midshaft diameter (I4) + Anteroposterior midshaft diameter (I5)] / 2) / Bicondylar length (I)

Proximal shaft ratio (PSR)

The anteroposterior and mediolateral shaft dimensions at the distal base of the lesser trochanter. Provides an estimate of the various loading forces that operate through the proximal femur. Proximal (subtrochanteric) anterior-posterior shaft diameter (13) / Proximal (subtrochanteric) medial-lateral shaft diameter (I2)

\section{Distal and proximal femur}

Proximal and distal condylar dimensions \#I (CDI)

Proximal and distal condylar dimensions \#2 $\left(\mathrm{CD}_{2}\right)$

\section{Distal femur}

Femoral epicondylar index (FEI)

Flatness of the condyles (CF)

Medial patellar lip ratio (MPLR)

Symmetry of the condyles (CS)

Distal femur Shape (DFS)
The mean of the bicondylar width and the proximal width divided by the functional length gives an indication of the relative size of both articulation joint areas. (Bicondylar width (I7) + Proximal width (2) / 2) / Bicondylar length (I)

The mean of the bicondylar width and the proximal width divided by the anteroposterior midshaft diameter provides an indication of the relative size of both articulation joint areas. (Bicondylar width (I7) + Proximal width (2) /2) / Mediolateral midshaft diameter (I4)

The epicondylar breadth of the femur divided by the functional length indicates the relative area available for the origins of the gastrocnemicus and soleus muscles used in extension of the knee and plantar-flexion of the pes. Bicondylar width (I7) / Bicondylar length (I)

The mean of the thicknesses of the medial and lateral condyles divided by the distal anteroposterior shaft diameter, indicates the flatness of the distal condyles and provides an estimate of the relative moment arm of the extensor muscles that cross the knee. (Thickness of the medial condyle (I8) + Thickness of the lateral condyle (I9)/2) / Anterior-posterior diameter of the distal shaft (I6)

The thickness of the medial condyle divided by the anteroposterior diameter of the distal shaft estimates the relative moment arm of the extensor muscles that cross the knee. Thickness of the medial condyle (I8) / Anteroposterior diameter of the distal shaft ( 16 )

The thickness of the medial condyle divided by the thickness of the lateral condyle provides an estimate of the symmetry of the condyles. Thickness of the medial condyle (I8) / Thickness of the lateral condyle (19)

The mean of the height of both condyles divided by the condylar breath indicates aspects of shape of the distal femur. ([Thickness of the medial condyle (I8) + Thickness of the lateral condyle (Ig)] / 2) / bicondylar width (I7) 
residuals of $\log _{\text {Iо }}$ transformed raw measurements (that were used for building the indices) were plotted against locomotor groups and subject to one-way ANOVAs, to assess whether the means among the locomotor groups were the same.

Principal Component Analysis (PCA) was used to identify the major components of variation among specimens (Zelditch et al., 2004). PCA was performed separately on the covariance matrices generated for each of the three data sets (33 raw measurements, I7 functional indices and species' means of the I7 functional indices). In each case some specimens for which a complete set of measurements was not available had to be removed. A multivariate analysis of variance (MANOVA) coupled with post hoc tests were performed on the Principal Component (PC) scores to examine differences between locomotor groups. Scores were only analysed from axes with eigenvalues that contributed significantly to sample variance, as estimated using the broken stick model ( $\mathrm{PC}_{1}, \mathrm{PC}_{2}$, and $\mathrm{PC}_{3}$ ) (Jackson, 1993).

Canonical Variates Analysis (CVA) was performed on the data set containing indices of all specimens, comprising representatives from each of the six locomotor groups. CVA produces linear combinations of variables (canonical variates) that best separate a priori defined groups, based on differences between those groups. Two CVAs were performed to test whether species could be classified into (I) their correct locomotor type and (2) their correct phylogenetic context (on the basis of their 'family' affiliation), using descriptors for the shape of their femora. A MANOVA was used to test for significant differences between groups for discrimination based upon (I) locomotor category and (2) phylogenetic group.

All statistical analyses were performed with JMP version Io.o.o (SAS Institute Inc., Cary, North Carolina).

\section{Results}

\section{Analysis of femoral raw measurements}

Regressions of $\log _{\text {Iо }}$ of all raw measurements against $\log _{\text {то }}$ body mass values revealed that all measurements, except the angle measurements, were highly correlated with body mass $\left(r^{2}=0.745^{-0.962,} F_{1,25-74}=76.104^{-1723.492}, P<0.000 \mathrm{I}\right)$. To assess the relationship between the residuals from these regressions and locomotor habits, oneway ANOVAs were computed. Six of the is measurements that were used to compute indices were found to be significantly correlated with locomotor group $(P<0.005)$. The indices CF, CS, DFS, HFI and MPLR whose numerator and denominator contain these measurements are therefore to be interpreted with caution.

\section{Analyses of femoral indices}

One-way ANOVAs and post hoc Tukey-Kramer HSD tests were conducted for femoral indices in relation to locomotor habit using (I) all investigated adult specimens, and (2) species' means (Table 19.4). When species means were constructed, the amount of variance between locomotor groups was found to decrease in ten indices. Ten of the indices (Table I9.4.) resulted in significant inter-locomotor group separation, and these 
Table 19.4 Results from one-way ANOVAs and post hoc Tukey-Kramer HSD tests of species' means of femoral morphological indices in Ctenohystrica (Caviomorpha, Phiomorpha, and Ctenodactylidae). Correlation coefficients $\left(r^{2}\right)$, number of species $(n), \mathrm{F}$-values $(F)$, and significance values $(P)$ of ANOVA together with group means are shown. For each index, locomotor habits that share the same letter represent homogenous subsets, as identified by post hoc tests.

\begin{tabular}{|c|c|c|c|c|c|c|c|c|c|c|}
\hline & GTI & HD & FNI & HFI & FRI & CDI & $\mathrm{CF}$ & MPLR & $\mathrm{CS}$ & DFS \\
\hline$r^{2}$ & 0.502 & o.6I7 & $0.55^{8}$ & 0.586 & 0.527 & 0.517 & 0.448 & 0.485 & 0.439 & 0.523 \\
\hline$n$ & 27 & 27 & $3 \mathrm{I}$ & 27 & 27 & 27 & 27 & 27 & 28 & 28 \\
\hline$F$ & 3.355 & 5.364 & 5.043 & 4.728 & 3.715 & 3.572 & 2.708 & 3.143 & $2.74 \mathrm{I}$ & 3.844 \\
\hline$P$ & 0.019 & 0.002 & 0.002 & 0.004 & 0.012 & 0.014 & 0.043 & 0.025 & 0.040 & 0.010 \\
\hline \multirow[t]{2}{*}{ unknown } & A, B & $\mathrm{A}, \mathrm{B}, \mathrm{C}$ & $\mathrm{A}, \mathrm{B}$ & A & A, B & A, B & A & A & A & $A, B$ \\
\hline & 0.042 & $0.05^{2}$ & 0.008 & 0.06I & 0.064 & 0.040 & 0.072 & 0.103 & 0.065 & -0.0173 \\
\hline \multirow[t]{2}{*}{ fossorial } & A & A & A & A & A & A & $\mathrm{A}, \mathrm{B}$ & $A, B$ & A, B & $A, B$ \\
\hline & 0.062 & 0.069 & 0.019 & $0.04 \mathrm{I}$ & 0.036 & 0.063 & -0.001 & 0.0003 & 0.004 & -0.035 \\
\hline \multirow[t]{2}{*}{ arboreal } & A, B & A, B & B & A & A, B & A, B & B & B & A, B & B \\
\hline & 0.002 & 0.083 & -0.088 & 0.026 & 0.025 & 0.023 & -0.III & - O.IIO & -0.006 & -0.178 \\
\hline \multirow{4}{*}{$\begin{array}{l}\text { semi- } \\
\text { aquatic } \\
\text { terrestrial }\end{array}$} & A, B & $\mathrm{A}, \mathrm{B}, \mathrm{C}$ & A, B & A, B & A, B & A, B & A, B & A,B & B & A \\
\hline & 0.003 & 0.002 & -0.008 & 0.006 & 0.013 & 0.0II & -0.007 & -0.018 & -0.022 & 0.036 \\
\hline & B & $\mathrm{B}, \mathrm{C}$ & A & A, B & A, B & B & A & A & A, B & A \\
\hline & -0.013 & -0.023 & 0.025 & -0.002 & -0.009 & -0.014 & 0.015 & 0.016 & 0.002 & $0.04 \mathrm{I}$ \\
\hline \multirow[t]{2}{*}{ scansorial } & $\mathrm{B}$ & $\mathrm{A}, \mathrm{B}, \mathrm{C}$ & $A, B$ & $\mathrm{~A}, \mathrm{~B}$ & A, B & A, B & A, B & A, B & A, B & A, B \\
\hline & -0.018 & -0.016 & -0.020 & -0.019 & -0.024 & -0.022 & 0.009 & 0.007 & -0.004 & -0.006 \\
\hline \multirow[t]{2}{*}{ cursorial } & B & $\mathrm{C}$ & A & B & A, B & B & A, B & $A, B$ & $\mathrm{~A}, \mathrm{~B}$ & A \\
\hline & -0.035 & -0.072 & 0.040 & -0.067 & -0.038 & -0.049 & -0.005 & -0.006 & -0.002 & 0.065 \\
\hline
\end{tabular}

comprised four indices of the proximal femur (GTI, HD, FNI, and HFI), one of the diaphysis (FRI), four indices of the distal femur (CF, MPLR, CS, and DFS), and one index of both the distal and proximal femur (CDI). HFI, GTI, and CDI separate cursorials from fossorials; MPLR, CF, and FNI separate terrestrials from arboreals; HD, GTI, and CDi separate terrestrials from cursorials. Care must be taken with the interpretation of GTI, HD, HFI, FRI, DCI, and DFS since bicondylar length, which is used as the numerator of these indices, is significantly correlated with locomotor group.

\section{Principal component analysis of femoral measurements and indices}

For the analysis of the I7 femoral indices, both the PCA conducted on data for all available specimens, and the one conducted on the pruned data set of species' means, resulted in significant separation of fossorial from terrestrial and cursorial rodents, and also arboreal from cursorial forms along PCI. This axis represented $36.0 \%\left(r^{2}=0.544\right.$, $\left.F_{6,55}=9.739, P<0.000 \mathrm{I}\right)$ and $38.47 \%\left(r^{2}=0.602, F_{6,24}=4.536, P=0.0057\right)$ of the variance in each sample, respectively (Figure 19.4). The separation of the arboreal group 

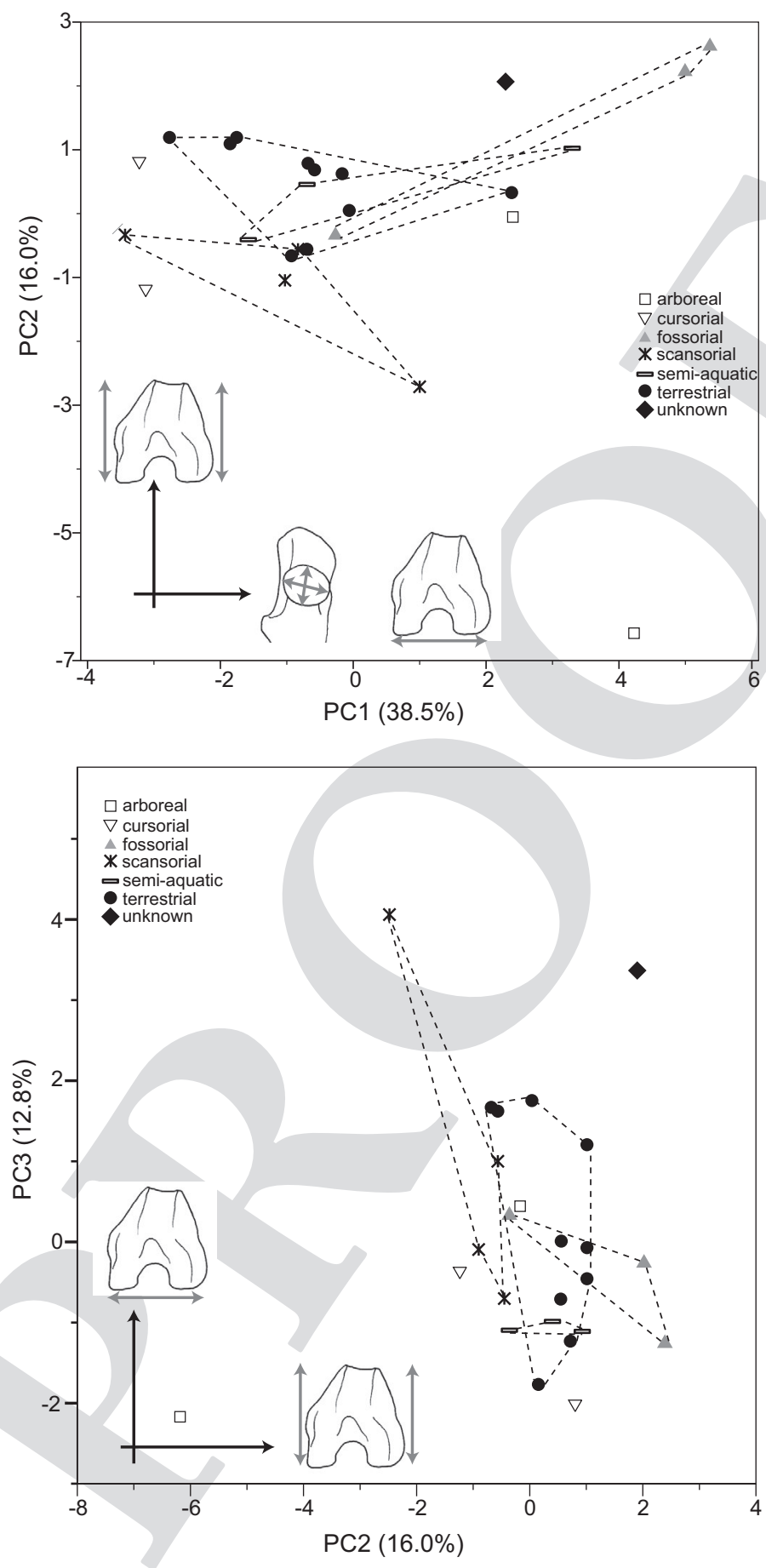

Figure 19.4 Results of Principal Component Analysis performed on species mean values of femoral indices in Ctenohystrica, showing $\mathrm{PC}_{\mathrm{I}}$ and $\mathrm{PC}_{2}$ (top), representing $54.5 \%$ of sample variance, and $\mathrm{PC}_{2}$ and $\mathrm{PC}_{3}$ (bottom), accounting for $26.2 \%$ of variance. Small illustrations indicate the femoral dimensions that are most highly correlated with each axis. 
Table 19.5A Summary of classification results for Canonical Variates Analysis (CVA) of I7 femoral indices using locomotor group as the classification variable.

\begin{tabular}{lccc}
\hline Locomotor group & $N$ correct & \% correct & Jackknifed \% correct \\
\hline arboreal & 4 & I00.0 & 33.3 \\
cursorial & I2 & 75.0 & 57.1 \\
fossorial & 3 & I00.0 & 100.0 \\
scansorial & 9 & 100.0 & 55.6 \\
semi-aquatic & 7 & 100.0 & 44.4 \\
terrestrial & I6 & 100.0 & 50.0 \\
\hline
\end{tabular}

is mainly due to Chaetomys supspinosus, a species that is represented by one specimen only. In the case of $\mathrm{PC}_{2}$, arboreals were found to be significantly separated from terrestrials and fossorials in the species' means dataset $\left(r^{2}=0.527, F_{6,24}=3.347, P=\right.$ $0.0215)$ but groups were not significantly separated in the dataset containing the indices of all available specimens. $\mathrm{PC}_{2}$ accounted for $\mathrm{I}_{3.3} \%$ in the sample including all available specimens and $\mathrm{I} 6.03 \%$ of the sample variance for the species' means data set.

The morphological indices (of species means) to which $\mathrm{PC}_{\mathrm{I}}$ was correlated strongly, that is the indices that contributed most to the variation in $\mathrm{PC}_{\mathrm{I}}$ (defined here as $r^{2}>$ o.6), are HD $\left(r^{2}=0.93 \mathrm{I}\right)$, CDI $\left(r^{2}=0.869\right)$, FEI $\left(r^{2}=0.845\right)$, GTI $\left(r^{2}=0.688\right)$, HFI $\left(r^{2}\right.$ $=0.678)$, and FRI $\left(r^{2}=0.609\right)$ (Figure I9.4). PCI was most strongly correlated with the dimension of the femoral head, as well as the dimensions of the proximal and distal part of the femur. Because values for FEI (femoral epicondylar index) were more strongly correlated with PCI than those for GTI (greater trochanter index), the breath of the distal condyles appear to have more influence on the overall variance between locomotor groups than does the breath of the proximal femur. $\mathrm{PC}_{\mathrm{I}}$ additionally explained variance associated with distance between the femoral head and the lesser trochanter, as well as the robustness of the femoral shaft. Correlation values for morphological indices in relation to $\mathrm{PC}_{2}$ and $\mathrm{PC}_{3}$ ranged from $r^{2}=2.149^{*}$ Io $^{-7}$ to 0.564 and $r^{2}=0.000$ I to 0.512 , respectively. The highest values for $r^{2}$ were found for $\mathrm{CF}$ in relation to $\mathrm{PC}_{2}$ and for $\mathrm{CD}_{2}$ in relation to $\mathrm{PC}_{3}$, in each case the index was significantly correlated to the $\mathrm{PC}$ axis $\left(F_{\mathrm{I}, 24}=29.75, P<0.000 \mathrm{I}\right.$ and $F_{\mathrm{I}, 24}=24.136, P<0.000 \mathrm{I}$, respectively) (Figure 19.4).

\section{Canonical variates analysis using locomotor type}

The canonical variates analyses that included all i 7 indices showed significant and clear separation of locomotor categories (Wilk's $\lambda=0.0094, F_{5,45}=3.138$, $P<0.000 \mathrm{I}$ ), as well as phylogenetic categories (Wilk's $\lambda=8.336^{*} \mathrm{IO}^{-7}, F_{\mathrm{I} 2,54}=3.255$, $P<$ 0.000I) (Table 19.5A; Figure 19.5). The first analysis, which used locomotor groups as the classifier variable, yielded three canonical functions with eigenvalues $>_{\mathrm{I}}$ and these accounted for $83.8 \%$ of the variance in the sample. The second analysis, in which 'family' affiliation was selected as the classifier variable, yielded six canonical functions 

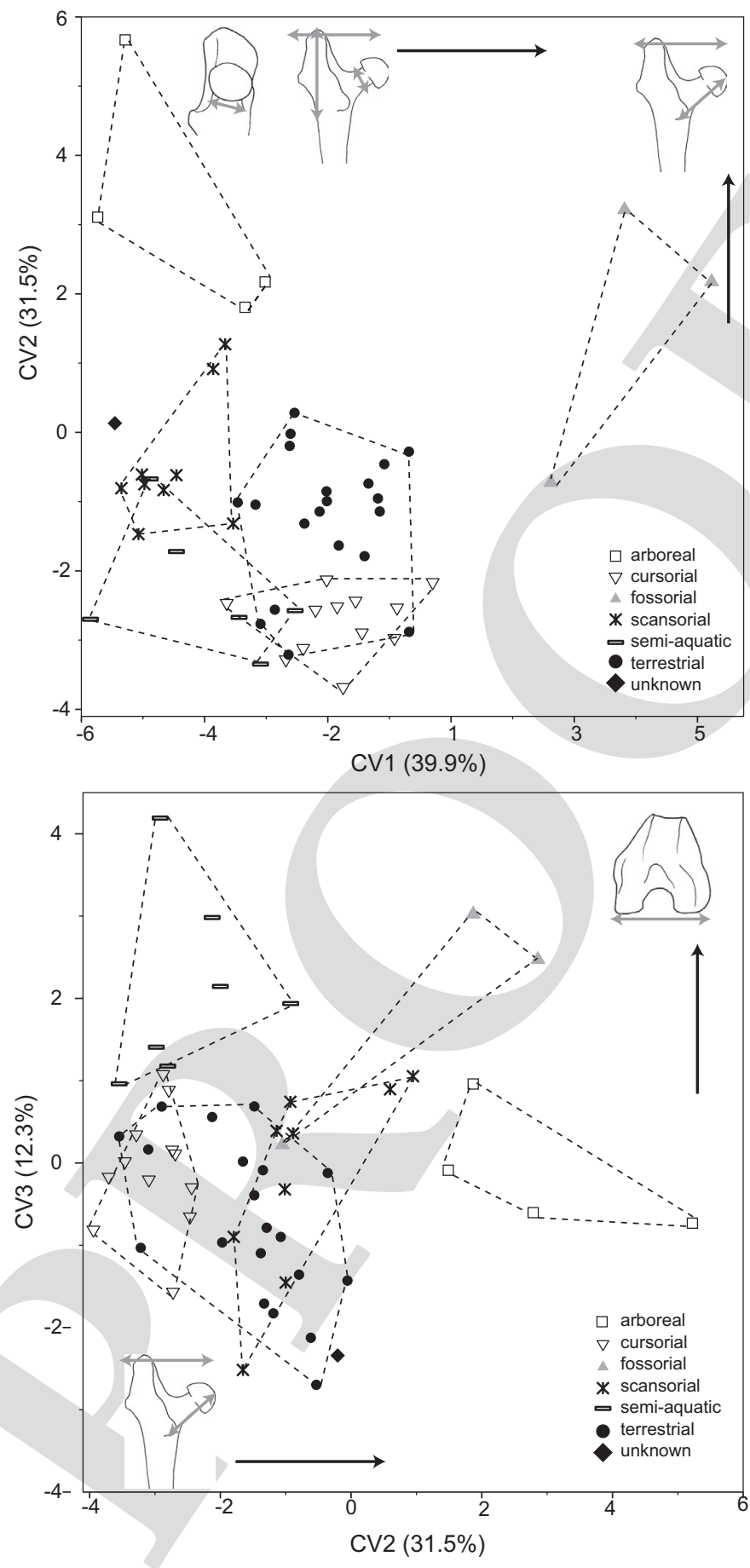

Figure 19.5 Canonical variates analysis (CVA) results for $\mathrm{I} 7$ femoral indices measured on representatives of Ctenohystrica, showing $\mathrm{CV}_{\mathrm{I}}$ and $\mathrm{CV}_{2}$ (top), and $\mathrm{CV}_{2}$ and $\mathrm{CV}_{3}$ (bottom). The data shown are separated using locomotor group as the classifier variable. 
with eigenvalues $>$ I, which together accounted for $96.5 \%$ of the sample variance. In the CVA using locomotor categories, the percentage of correctly assigned individuals ranged from $75 \%$ to $100 \%$ per group (Table 19.5A), and three species ( $7.3 \%$ of all specimens) were misclassified (Table 19.5B). These were one specimen of Cavia porcellus, one specimen of Proechimys guyannensis and two specimens of Cuniculus paca. All four specimens were classified as being cursorial rather than terrestrial (Table 19.5B). In the second CVA using phylogenetic categories, no specimens were misclassified. The fossil NMB SA-259 was classified to be terrestrial with a probability of 5 I. $2 \%$ and to be related to the Hydrochoeridae with a probability of $100 \%$ (Table 19.5B).

The first canonical function $(\mathrm{CVI})$ of locomotor categories was most strongly correlated with GTI $\left(r^{2}=0.228, F_{\mathrm{I}, 45}=15.668, P=0.0002\right)$, and also positively correlated with GI, FNI, and CDi (Figure 19.5). Separation between locomotor categories on $\mathrm{CV}_{\mathrm{I}}$ was therefore related to the relative length and breadth of the proximal articular surfaces, the breath of the distal articular surfaces, and to the shape of the femoral neck. MANOVA and post hoc test results showed that three distinct groups could be distinguished on CVI $\left(r^{2}=0.780, \mathrm{~F}_{5,54}=34.839, P<\right.$ ○.००or). One group contained the fossorial species that all had positive values for $\mathrm{CV}$, whereas all other groups showed negative values (Figure 19.5). A second group contained the cursorial and terrestrial rodents that were more similar to each other, and the third group comprised the semi-aquatic, scansorial, and arboreal Ctenohystrica. The second canonical function $\left(\mathrm{CV}_{2}\right)$ was positively correlated with GTI, HFI, HD, FRI, CDI, FEI, DLT, and negatively correlated with DFS and FNI. Similar to $\mathrm{CV}_{\mathrm{I}}, \mathrm{CV}_{2}$ was also related to the dimensions of the proximal and distal articular areas of the femur and femoral neck shape. Additionally, $\mathrm{CV}_{2}$ explained differences related to shaft diameter, dimensions of the lesser trochanter and dimensions of the femoral head. These differences significantly separated arboreal and fossorial species that were located at the positive end of $\mathrm{CV}_{2}$, from other groups $\left(r^{2}=0.7 \mathrm{II}, \mathrm{F}_{5,54}=27.542, P<\right.$ 0.000I) (Figure I9.5). $\mathrm{CV}_{3}$ was also positively correlated with FRI, FEI, CDI, GTI, and HD but negatively correlated with CS. This function separated semi-aquatic and fossorial species from cursorial, arboreal, scansorial and terrestrial species $\left(r^{2}=0.474, \mathrm{~F}_{5,54}=10.762, P<0.0001\right)$ (Figure 19.5).

\section{Discussion}

The combined investigation of indices and measurements of the femur in this sample of Ctenohystrica revealed some clear anatomical differences associated with locomotor habit, particularly between fossorial and cursorial rodents, and between arboreal compared to cursorial and terrestrial rodents. These results reveal potential for the use of femoral descriptors to help provide insights into the paleobiology of extinct rodents. We focus our discussion on inter-locomotor differences in the proximal and distal femur and the femoral diaphyses. 
Table 19.5B Classification results for canonical variates analysis using values for 17 femoral indices. Specimens were assigned a priori to locomotor groups. Observed and predicted classification and associated probability of each specimen is provided. The attribution of the fossil cf. Phoberomys sp, (NMB SA-259) is given at the bottom of the table. Asterisks indicate misclassification.

\begin{tabular}{|c|c|c|c|c|}
\hline Specimens & Observed & Predicted & $\begin{array}{l}\text { Probability } \\
\text { (prediction) }\end{array}$ & Others \\
\hline Cryptomys hottentotus & fossorial & fossorial & 1.0000 & \\
\hline Georychus capensis & fossorial & fossorial & I.0000 & \\
\hline Cavia porcellus & terrestrial & terrestrial & $0.668 \mathrm{I}$ & cursorial 0.33 \\
\hline Cavia porcellus & terrestrial & cursorial* & 0.5538 & \\
\hline Dolichotis patagonum & cursorial & cursorial & 0.9929 & \\
\hline Dolichotis patagonum & cursorial & cursorial & $0.86 \mathrm{II}$ & terrestrial o.I3 \\
\hline Dolichotis patagonum & cursorial & cursorial & 0.9329 & \\
\hline Dolichotis patagonum & cursorial & cursorial & 0.9976 & \\
\hline Dolichotis patagonum & cursorial & cursorial & 0.9997 & \\
\hline Galea musteloides & terrestrial & terrestrial & $0.697 \mathrm{I}$ & cursorial 0.30 \\
\hline Chinchilla lanigera & scansorial & scansorial & 0.9986 & \\
\hline Chinchilla lanigera & scansorial & scansorial & 0.9982 & \\
\hline Chinchilla lanigera & scansorial & scansorial & 0.9985 & \\
\hline Chinchilla lanigera & scansorial & scansorial & 0.9997 & \\
\hline Chinchilla lanigera & scansorial & scansorial & 0.9988 & \\
\hline Chinchilla spec. & scansorial & scansorial & $0.92 \mathrm{II}$ & \\
\hline Lagostomus maximus & terrestrial & terrestrial & 0.9653 & \\
\hline Lagostomus maximus & terrestrial & terrestrial & 0.8992 & \\
\hline Lagostomus maximus & terrestrial & terrestrial & 0.946 & \\
\hline Lagostomus maximus & terrestrial & terrestrial & 0.7714 & scansorial o.I7 \\
\hline Ctenodactylus vali & terrestrial & terrestrial & 0.9916 & \\
\hline Ctenodactylus vali & terrestrial & terrestrial & 0.9967 & \\
\hline Massoutiera mzabi & terrestrial & terrestrial & 0.9290 & \\
\hline Pectinator spekei & terrestrial & terrestrial & 0.9793 & \\
\hline Pectinator spekei & terrestrial & terrestrial & 0.9982 & \\
\hline Cuniculus paca & terrestrial & cursorial* & 0.8049 & \\
\hline Cuniculus paca & terrestrial & cursorial* & 0.4922 & semi-aquatic o.19 \\
\hline Dasyprocta leporina & cursorial & cursorial & 0.9677 & \\
\hline Dasyprocta leporina & cursorial & cursorial & 0.6700 & terrestrial 0.33 \\
\hline Dasyprocta leporina & cursorial & cursorial & 0.8545 & terrestrial O.I4 \\
\hline Dasyprocta leporina & cursorial & cursorial & 0.9046 & \\
\hline Dasyprocta leporina & cursorial & cursorial & 0.6259 & $\begin{array}{l}\text { semi-aquatic o.I6 } \\
\text { terrestrial o.I5 }\end{array}$ \\
\hline Myoprocta pratti & cursorial & cursorial & 0.6885 & terrestrial $0.3 \mathrm{I}$ \\
\hline Myoprocta pratti & cursorial & cursorial & 0.9672 & \\
\hline Dinomys branickii & scansorial & scansorial & 0.8662 & \\
\hline Clyomys laticeps & fossorial & fossorial & 0.9840 & \\
\hline
\end{tabular}


Table 19.5B (cont.)

\begin{tabular}{|c|c|c|c|c|}
\hline Specimens & Observed & Predicted & $\begin{array}{l}\text { Probability } \\
\text { (prediction) }\end{array}$ & Others \\
\hline Proechimys guyannensis & terrestrial & cursorial* & 0.4042 & semi-aquatic o.I9 \\
\hline Chaetomys subspinosus & arboreal & arboreal & 1.0000 & \\
\hline Coendou prehensilis & arboreal & arboreal & 0.9998 & \\
\hline Coendou prehensilis & arboreal & arboreal & 0.9983 & \\
\hline Coendou prehensilis & arboreal & arboreal & 0.9771 & \\
\hline Eretbizon dorsatum & scansorial & scansorial & 0.9765 & \\
\hline Erethizon dorsatum & scansorial & scansorial & 0.5826 & arboreal $0.3 \mathrm{I}$ \\
\hline Hydrochoeris hydrochaeris & semi-aquatic & semi-aquatic & 0.9998 & \\
\hline Hydrochoeris hydrochaeris & semi-aquatic & semi-aquatic & 0.8090 & scansorial o.18 \\
\hline Hydrochoeris hydrochaeris & semi-aquatic & semi-aquatic & 0.9995 & \\
\hline Hystrix cristata & terrestrial & terrestrial & 0.9976 & \\
\hline Hystrix cristata & terrestrial & terrestrial & 0.8604 & scansorial o.12 \\
\hline Hystrix indica & terrestrial & terrestrial & $0.95 \mathrm{I} 7$ & \\
\hline Hystrix spec. & terrestrial & terrestrial & 0.9993 & \\
\hline Myocastor coypus & semi-aquatic & semi-aquatic & 1.0000 & \\
\hline Myocastor coypus & semi-aquatic & semi-aquatic & 0.9963 & \\
\hline Thryonomys gregorianus & terrestrial & terrestrial & $0.739 \mathrm{I}$ & semi-aquatic o.I9 \\
\hline Thryonomys swinderianus & semi-aquatic & semi-aquatic & 0.5394 & terrestrial 0.42 \\
\hline Thryonomys swinderianus & semi-aquatic & semi-aquatic & $0.56 \mathrm{I} 7$ & cursorial 0.36 \\
\hline $\begin{array}{l}\text { cf. Phoberomys sp. } \\
\text { (NMBE SA-259) }\end{array}$ & unknown & terrestrial & $0.5 \mathrm{II} 6$ & $\begin{array}{l}\text { arboreal } 0.28 \\
\text { scansorial } 0.2 \mathrm{I}\end{array}$ \\
\hline
\end{tabular}

\section{The proximal femur}

The hip flexor index (HFI), gluteal index (GI) and greater trochanter index (GTI) are hypothesized to be correlated with cursorial and fossorial locomotor habits because the lesser trochanter and the greater trochanter are important muscle attachment sites, and those indices measure the relative distances from the trochanters to the proximal end of the femur. These distances are not true measures of the muscular moment arm involved, but they are closely correlated, since the moment arm will increase as their insertion is prolonged distally. Therefore, a proximally restricted muscle attachment site results in a shorter moment arm and a consequent decrease in mechanical advantage. Values for HFI, GI and GTI were therefore hypothesized to be enlarged in cursorial, semi-aquatic and fossorial species, because these locomotor habits require large lever arms for major extensor muscles (Turvey et al., 2006; Polly, 2007), compared to the other groups. As predicted, the relative width of the proximal femur (GTI) and the distance from the femoral head to the lesser trochanter (HFI) were both large in fossorial members of Ctenohystrica. Nevertheless, in contrast to our predications, semi-aquatic species did not display significantly large or small values for HFI, 
GI or GTI, and cursorial species were found to have small values for HFI. Hence, considerable variability in these indices is apparent among locomotor groups, and this may be the result of the influence of other morphological structures: the relative size of the femoral head, the length of the femoral neck and its angle in relation to the femoral shaft, the proximal shaft thickness and the lateral greater trochanter protrusion are all directly related to GTI values. Notably, femoral head dimension (HD) was correlated with GTI $\left(r^{2}=0.626, F_{\mathrm{I}, 26}=4 \mathrm{I} .837, P<0.00 \mathrm{I}\right)$ and HFI $\left(r^{2}=0.6 \mathrm{II}, F_{\mathrm{I}, 26}=39.256, P<\right.$ 0.0oI). HD provides an indication of the relative size of the femoral head, which was found to be largest among arboreal and fossorial species, and smallest in cursorial species. This result supports the prediction that climbing and digging species require increased hip mobility, which in part may be achieved through increased rotational capacity afforded by a large femoral head (White, 1993), but also indicates that the large values observed here for GTI in fossorial species and for HFI in arboreal and fossorial species may be a function of both an increase in lever arm leading to a longer femoral neck and/or an increased proximal shaft thickness and a large femoral head.

We did not find a relationship between condylar-diaphyseal angle and locomotor type for any of the examined species. Arboreal species were expected to have more proximally oriented femoral heads (i.e. wider angles) than non-arboreal species in order to increase hip mobility (White, 1993; Turvey et al. 2006). The absence of locomotory signal observed for Ctenohystrica likely reflects the high levels of intraspecific variation in the condylar-diaphyseal angle in the sample, for example this measurement for Dasyprocta leporina, Myocastor coypus, and Lagostomus maximus varied between $120^{\circ}-\mathrm{I}_{3} 0^{\circ}$, $\mathrm{II} 4^{\circ}-\mathrm{I} 29^{\circ}$, and $120^{\circ}-\mathrm{I} 35^{\circ}$, respectively. This magnitude of variability was greater than inter-locomotor type variance, and members of Ctenohystrica are not unique in showing such variation in this angle, as similar magnitudes of variation have been reported for humans (Kapandji, 1985).

Arboreal members of Ctenohystrica were found to have a significant smaller value for femoral neck index (FNI) than fossorial, terrestrial and cursorial species. Considering the results of regressions using the raw measurements, this difference is due to an enlarged vertical neck diameter in arboreals, rather than a small anteroposterior neck diameter. The observed vertical thickening may be related to specific loadings during arboreal climbing.

\section{The femoral diaphyses}

Even though not statistically significant, variation in the femur robustness index (FRI) showed that fossorial species have very thick femoral shafts, whereas cursorials have comparatively thinner femoral shafts. These results are in agreement with observations that the femoral shaft of fossorial mammals is typically robust, reflecting a response of the bone to supporting the development of large, powerful muscles that are required to generate forces for digging (Hildebrand and Goslow, 2004), and to further withstand the compressive and torsional stresses resulting from this activity (Biknevicius, I993). In contrast, the narrow femoral shaft in cursorial 
species reflects the overall more gracile postcranial elements in those animals to minimize locomotory energy costs, because although short in-levers and long outlevers results in a rapid translation of the manus and pes, comparatively little power is produced. The same reasoning leads to the reduction of digits, as for example in maras (Dolichotis spp.). Our results are congruent with those of Elissamburu and Vizcaíno (2004), who recovered a functional sequence of adaptations in the limb proportions of caviomorphs, which followed cursorial-generalized-occasional diggers-diggers, and specifically in the hindlimb this reflected a decrease in the index of speed efficiency of the femur along the sequence from cursorial to digging species, as well as an increase in limb robustness. Similarly, Samuels and Van Valkenburgh (2008) found that fossorial rodents showed a more robust humerus, femur and ulna in comparison to other groups and using measures that captured shaft diameter.

\section{The distal femur}

Arboreal species were found to have flatter distal condyles compared to other locomotor groups, most notably evidenced in comparison to terrestrial species that had significantly larger values for CF (flatness of the condyles) and DFS (shape of the distal femur). This corresponds well with the observed trend that arboreal mammals require flat distal condyles in order to generate greater mobility in the knee joint by having a relative wide condylar surface and a broad and shallow patellar groove (White, 1993; Turvey et al., 2006). Similarly, arboreal rodents also had flatter medial condyles, and hence significantly lower values for the medial patellar lip ratio (MPLR), which captured the thickness of the medial condyle and provided an estimation of the relative moment arm of the extensor muscles crossing the knee. Terrestrial and cursorial species on the other hand have anteroposteriorally thicker and mediolaterally narrower distal condyles in order to stabilize and increase moment arms of the joint (Kappelman, I988).

\section{Patterns in morphospace of femoral measurements and locomotor inferences for fossil taxa}

The results of Principal Component Analysis mainly revealed differences between arboreal species compared to terrestrial and cursorial species, specifically concerning the dimension of the femoral head, the dimensions of the distal and proximal condyles, the distance between the femoral head and the lesser trochanter, and the robustness of the femoral shaft. These results corroborate some findings of skeletal adaptations in terrestrial, cursorial, and arboreal rodents (Elissamburu and Vizcaíno, 2004; Samuels and Van Valkenburgh, 2008): the femora of arboreal mammals are characterized by a relatively large femoral head which increases the hip mobility (White, 1993), a distally oriented lesser trochanter, and flat and broad distal condyles which allows for more knee rotation during climbing (Turvey et al., 2006). In contrast, terrestrial and cursorial species are characterized by having small femoral heads. The PCA results also indicated considerable variability in femoral morphology within 
members of each locomotor category, as has similarly been documented for other studies of postcranial elements, such as the humerus (Morgan and Álvarez, 2013), and scapula (Morgan, 2009) in caviomorph rodents. Elissamburu and Vizcaíno (2004) drew parallels between limb specializations observed in caviomorphs and those of other outgroups, such as armadillos, that are more restricted in their locomotory activities, being specialized to burrowing and digging. Those authors noted that caviomorphs have developed the same trends in moment arms relationships and the same muscle groups as specialized diggers such as the armadillos. Similarly, hindlimb specializations evidenced in cursorial caviomorphs were compared to those displayed among members of Carnivora that adopt a cursorial mode of locomotion (Elissamburu and Vizcaíno, 2004). The high variability in some features of the femur may reflect the overall lack of highly specialized forms among Ctenohystrica (Weisbecker and Schmid, 2007), but should also be considered more broadly in the context of other postcranial elements. The anatomy of the femur is a fundamental factor that determines the way and the range a limb can be moved and hence an important subject for functional study, nevertheless limb elements are serially repeated homologous structures that do not function in isolation. Therefore, some of the femoral traits analysed herein likely covary with measurements for other postcranial elements and not just directly with locomotor habit. Indeed, such functionally induced covariances have been recovered among other mammals (see Sears, 2004; Young et al., 2010), and provide a promising avenue to further understand the evolution of morphological constraint in the rodent postcranial skeleton. Herein our focus on the femur takes advantage not only of it being one of the most functionally diagnostic postcranial elements, but also one that is often well preserved in the fossil record, and of which there exist a number of specimens from giant extinct taxa (Geiger et al., 2013). Canonical variates analysis of all femoral indices yielded high levels of success in classification and encouraging results for the potential of inferring locomotory type in fossil taxa. For the well-preserved fossil NMB SA-259, for which all measurements could be taken and body mass estimations were available, the results of the CVA classified the specimen as being terrestrial but closely related to Hydrochoeris. Other giant neotropical rodents have been reconstructed as potentially having a similar lifestyle to Hydrochoeris, notably the tooth wear patterns of Phoberomys pattersoni have been suggested to be similar to those of mammals that eat sea grasses (Horovitz et al., 2010), as capybaras do (Creed, 2004). The estimated body mass of NMB SA-259 of around $400 \mathrm{~kg}$ (Geiger et al., 2013) far exceeds that of Hydrochoeris, which is the closest extant analogue in terms of size. Nevertheless, similarities in overall femoral morphology of both species might reflect allometrically related adaptations due to a relatively high body mass, particularly a mass above $300 \mathrm{~kg}$ may reduce locomotor performance and result in strong bone allometry in terms of both bone diameter and muscle moment arm, i.e. mechanical advantage (Biewener, I990; Geiger et al., 2013). Given such a mass, it is likely that NMB SA-259 was too heavy to adopt a scansorial lifestyle, and exclusive fossoriality is equally unlikely given that small body size is a typical adaptation of fossorial species (Contreras, I986). NMB SA-259 may have been 
an occasional digger, similar to most extant caviomorphs, and we hypothesize most probably a terrestrial species that was closely bound to aquatic environments.

\section{Summary}

An understanding of macroevolutionary patterns of postcranial morphology provides important insights into the evolution of functional adaptations to locomotory behaviours, as well as the opportunity to consider palaeobiological aspects of fossil species. Using a range of measurements and indices, we here quantify variation in femoral shape for a broad sample of species belonging to Ctenohystrica. We identify a series of functionally important features of the femur, which permit fossorial and arboreal species to be distinguished from cursorial and terrestrial species. These features mainly concern the dimension of the femoral head, the proximal and distal condyles, the distance between the femoral head and the lesser trochanter, and the robustness of the femoral shaft. The ecomorphological diversification of Ctenohystrica is exemplified by the considerable variation in femoral morphology among the samples studied here, and our analyses provide a framework and hypotheses to consider for future assessments of well-preserved femora in fossil rodents.

\section{Acknowledgements}

We thank Lionel Hautier and Phil Cox for inviting us to contribute to this volume. LABW is supported by a postdoctoral fellowship from the Swiss National

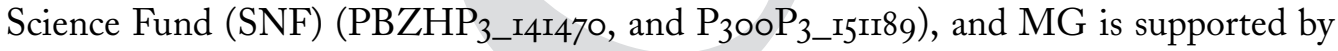
the Forschungskredit of the University of Zurich (FK-I3-088). We thank Marcelo Sánchez and members of the Palaeontological Institute and Museum (University of Zürich, Switzerland), for helpful comments and discussions on the topics presented here.

\section{REFERENCES}

Abderhalden, E. (1938). Handbuch der biologischen Arbeitsmethoden, Abt. 7, Teil 2, Heft 3. Vienna: Verlag Urban und Schwarzenberg.

Álvarez, A., Perez, S. I. and Verzi, D. H. (2orra). Early evolutionary differentiation of morphological variation in the mandible of South American caviomorph rodents (Rodentia, Caviomorpha).

Journal of Evolutionary Biology, 24, 2687-2695.

Álvarez, A., Perez, S. I. and Verzi, D. H. (2orrb). Ecological and phylogenetic influence on mandible shape variation of South American caviomorph rodents (Rodentia: Hystricomorpha). Biological Journal of the Linnean Society, 102, 828-837.

Anemone, R. L. (1990). The VCL hypothesis revisited: patterns of femoral morphology among quadrupedal and saltatorial prosimian primates. American Journal of Physical Anthropology, 83, $373^{-} 393$. 
Argot, C. (200I). Functional-adaptive anatomy of the forelimb in the Didelphidae, and the paleobiology of the Paleocene marsupials Mayulestes ferox and Pucadelphys andinus. Journal of Morphology, 247, 5I-79.

Argot, C. (2004). Functional-adaptive features and palaeobiologic implications of the postcranial skeleton of the Late Miocene sabretooth borhyaenoid Thylacosmilus atrox (Metatheria). Alcheringa, 28, 229-266.

Biewener, A. A. (1990). Biomechanics of mammalian terrestrial locomotion. Science, 250, I097-IIO3.

Biknevicius, A. R. (1993). Biomechanical scaling of limb bones and differential limb use in caviomorph rodents. Journal of Mammalogy, 74 (I), 95-107.

Buikstra, J. E. and Ubelaker, D. H. (1994). Standards for data collection from human skeletal remains. Arkansas Archeological Survey Research Series, 44, 68 (I).

Contreras, L. C. (1986). Bioenergetics and distribution of fossorial Spalacopus cyanus (Rodentia): thermal stress, or cost of burrowing. Physiological Zoology, 59(r), 20-28.

Cox, P. G., Rayfield, E. J., Fagan, M. J. et al. (2012). Functional evolution of the feeding system in rodents. PLOS ONE, $7(4), \mathrm{e}_{3} 6299$.

Creed, J. C. (2004). Capybara (Hydrochaeris hydrochaeris Rodentia: Hydrochaeridae): a mammalian seagrass herbivore. Coastal and Estuarine Research Federation, 27(2), 197-200.

Elissamburu, A. and De Santis, L. (20II). Forelimb proportions and fossorial adaptations in the scratch-digging rodent Ctenomys (Caviomorpha). Journal of Mammalogy, 92(3), 683-689.

Elissamburu, A. and Vizcaíno, S. F. (2004). Limb proportions and adaptations in caviomorph rodents (Rodentia: Caviomorpha). Journal of Zoology, 262, I45-I59.

Fabre, P.-H., Hautier, L., Dimitrov, D., and Douzery, E. J. P. 2or2. A glimpse on the pattern of rodent diversification: a phylogenetic approach. BMC Evolutionary Biology, 12, 88.

Geiger, M., Wilson L. A. B., Costeur L., Sánchez, R. and Sánchez-Villagra, M. R. (2013). Diversity and body size in giant caviomorphs (Rodentia) from the northern neotropics - a study of femoral variation. Journal of Vertebrate Paleontology, 33, I449-I456

Harmon, E. H. (2006). Size and shape variation in Australopithecus afarensis proximal femora. Journal of Human Evolution, 5I, 217-227.

Hautier, L., Lebrun, R., Saksiri, S. et al. (20II). Hystricognathy vs. Sciurognathy in the rodent jaw: a new morphometric assessment of hystricognathy applied to the living fossil Laonastes (Diatomyidae). PLOS ONE, 6(4), ei8698.

Hautier, L., Lebrun, R. and Cox, P. G. (20I2). Patterns of covariation in the masticatory apparatus of hystricognathous rodents: implications for evolution and diversification. Journal of Morphology, 273( 12$),$ I319-1337.

Hermann, B., Grupe, G., Hummel, S., Piepenbrink, H. and Schutkowski, H. (1990). Prähistorische Anthropologie - Leitfaden der Feld-und Labormethoden. Berlin: Springer-Verlag.

Hildebrand, M. and Goslow, G. E. (2004). Vergleichende und funktionelle Anatomie der Wirbeltiere. Berlin: Springer-Verlag.

Horovitz, I., Sánchez-Villagra, M. R, Martin, T. and Aguilera, O. A. (2006). The fossil record of Phoberomys pattersoni Mones 1980 (Mammalia, Rodentia) from Urumaco (Late Miocene, Venezuela), with an analysis of its phylogenetic relationships. Journal of Systematic Palaeontology, 4(3), 293-306.

Horovitz, I., Sánchez-Villagra, M. R., Vucetich, M. G. and Aguilera, O. A. (2010). Fossil rodents from the Late Miocene Urumaco and Middle Miocene Cumaca formations, Venezuela. In Urumaco and Venezuelan Paleontology - The Fossil Record of the Northern Neotropics, eds. M. R. Sánchez-Villagra, O. Aguilera and A. A. Cardini. Bloomington: Indiana University Press. 
Huchon, D., Madsen, O., Sibbald, M. J. J. B. et al. (2002). Rodent phylogeny and a timescale for the evolution of Glires: evidence from an extensive taxon sampling using three nuclear genes. Molecular Biology and Evolution, 19(7), 1053-1065.

IUCN 20Ir. IUCN Red List of Threatened Species. Version 20II.I. http://www.iucnredlist.org. downloaded on ist of June 2011.

Jackson, D. A. (1993). Stopping rules in principal components analysis: a comparison of heuristical and statistical approaches. Ecology, 74(8), 2204-22I4.

Jones, K. E., Bielby, J., Cardillo, M. et al. (2009). PanTHERIA: a species-level database of life history, ecology, and geography of extant and recently extinct mammals. Ecology, 9o (9), 2648-2648.

Kapandji, I. A. (1985). Funktionelle Anatomie der Gelenke, Band 2: Untere Extremität. Stuttgart: Ferdinand Enke Verlag.

Kappelman, J. (I988). Morphology and locomotor adaptations of the bovid femur in relation to habitat. Journal of Morphology, 198, II9-130.

Kley, N. J. and Kearney, M. (2007). Adpatations for digging and burrowing. In Fins into Limbs: Evolution, Development, and Transformation, ed. B. K. Hall. Chicago: University of Chicago Press, pp. 384-309.

Knussmann, R. (I980). Anthropologie: Handbuch der vergleichenden Biologie des Menschen, Band I, Teil I. Stuttgart: Gustav Fischer Verlag.

Kugler, H. K. (200I). Treatise on the Geology of Trinidad. Part 4: the Paleocene to Holocene Formations. Basel: Museum of Natural History.

Lessa, E. P., Vassallo, A. I., Verzi, D. H. and Mora, M. S. (2008). Evolution of morphological adaptations for digging in living and extinct ctenomyid and octodontid rodents. Biological Journal of the Linnean Society, 95, 267-283.

MacDonald, D. W. (2009). The Encyclopaedia of Mammals. Oxford: Oxford University Press.

Meachen-Samuels, J. (2010). Comparative scaling of humeral cross-sections of felids and canids using radiographic images. Journal of Mammalian Evolution, 17, 193-209.

McHenry, H. M. and Corruccini, R. S. (1978). The femur in early human evolution. American Journal of Physical Anthropology, 49, 473-488.

Morgan, C. C. (2009). Geometric mophometrics of the scapula of South American caviomorph rodents (Rodentia: Hystricognathi): form, function and phylogeny. Mammalian Biology, 74, 497-506.

Morgan, C. C. and Álvarez, A. (2013). The humerus of South American caviomorph rodents: shape, function and size in a phylogenetic context. Journal of Zoology, 290(2), 107-II6.

Morgan, C. C. and Verzi, D. H. (20II). Carpal-metacarpal specializations for burrowing in South American octodontid rodents. Journal of Anatomy, 219(2), I67-175.

Nowak, R. M., (1999). Walker's Mammals of the World, 6th edn. Baltimore: John Hopkins University Press.

Polly, D. P. (2007). Limbs in mammalian evolution. In Fins into Limbs: Evolution, Development, and Transformation, ed. B. K. Hall. Chicago: University Chicago Press, pp. 245-268.

Poux, C., Chevret, P., Huchon, D., de Jong, W. W. and Douzery, E. J. P. (2006). Arrival and diversification of caviomorph rodents and platyrrhine primates in South America. Systematic Biology, 55, 228-244.

Rinderknecht, A. and Blanco, R. E. (2008). The largest fossil rodent. Proceedings of the Royal Society $B, \mathbf{2 7 5}, 923-928$.

Rinderknecht, A. and Bostelmann, E. E. (20II). New genus of giant Dinomyidae (Rodentia: Hystricognathi: Caviomorpha) from the late Miocene of Uruguay. Journal of Mammalogy, 92(I), I69-I78. 
Rowe, D. L., Dunn, K. A., Adkins, R. M. and Honeycutt, R. L. (20I0). Molecular clocks keep dispersal hypotheses afloat: evidence for trans-Atlantic rafting by rodents. Journal of Biogeography, 37, 305-324.

Samuels, J. X. and Van Valkenburgh, B. (2008). Skeletal indicators of locomotor adaptations in living and extinct rodents. Journal of Morphology, 269, I387-I4II.

Samuels, J. X., Meachen, J. A. and Sakai, S. A. (2013). Postcranial morphology and the locomotor habits of living and extinct carnivorans. Journal of Morphology, 274(2), I2I-I46.

Sánchez-Villagra, M. R., Aguilera, O. A. and Horovitz, I. (2003). The anatomy of the world's largest extinct rodent. Science, 30I, 1708-1710.

Schaller, O. (2007). Illustrated veterinary anatomical nomenclature. Stuttgart: Enke Verlag in MSV Medizinverlage Stuttgart Gm.

Schaub, S. (1935). Säugetierfunde aus Venezuela und Trinidad, Band 55. Basel: Kommissionsverlag von E. Birkhäuser \& Cie.

Scheuer, L. and Black, S. (200o). Developmental Juvenile Osteology. Amsterdam: Elsevier Academic Press.

Schünke, M., (2000). Funktionelle Anatomie - Topographie und Function des Bewegungssystems. Stuttgart: Georg Thieme Verlag.

Sears, K. E. (2004). Constraints on the morphological evolution of marsupial shoulder girdles. Evolution, 58(10), 2353-2370.

Seckel, L. and Janis, C. (2008). Convergences in scapula morphology among small cursorial mammals: an osteological correlate for locomotory specialization. Journal of Mammalian Evolution, 15, 26I-279.

Serrat, M. A., Reno, P. L., McCollum, M. A., Meindl, R. S. and Lovejoy, C. O. (2007). Variation in mammalian proximal femoral development: comparative analysis of two distinct ossification patterns. Journal of Anatomy, 210, 249-258.

Starck, D., 1979. Vergleichende Anatomie der Wirbeltiere auf evolutionsbiologischer Grundlage. Buch 2: Das Skelettsystem. Berlin: Springer Verlag.

Steiner-Souza, F., De Freitas, T. R. O. and Cordeiro-Estrela, P. (2010). Inferring adaptation within shape diversity of the humerus of subterranean rodent Ctenomys. Biological Journal of the Linnean Society, 100(2), 353-367.

Turvey, S. T., Grady, F. V. and Rye, P. (2006). A new genus and species of 'giant hutia' (Tainotherium valei) from the Quaternary of Puerto Rico: an extinct arboreal quadruped? Journal of Zoology, 270, 585-594.

Van Valkenburgh, B. (1987). Skeletal indicators of locomotor behavior in living and extinct carnivores. Journal of Vertebrate Paleontology, 7, 162-182.

Verzi, D. H., Álvarez, A., Olivares, A. I., Morgan, C. C. and Vassallo, A. I. (20I0). Ontogenetic trajectories of key morphofunctional cranial traits in South American subterranean ctenomyid rodents. Journal of Mammalogy, 9I(6), I508-I516.

Vizcaíno, S. F. and Milne, N. (2002). Structure and function in armadillo limbs (Mammalia: Xenarthra: Dasypodidae). Journal of Zoology, 257, II7-172.

Voss, H., and Herrlinger, R. (1975). Taschenbuch der Anatomie-Band I: Einführung in die Anatomie/ Bewegungsapparat. Stuttgart: Gustav Fischer Verlag.

Walker, D. N. (1987). Sequence of epiphyseal fusion in the Rocky Mountain bighorn sheep. Great Basin Naturalist, 47 (I), 7-I2.

Weisbecker, V. and Schmid, S. (2007). Autopodial skeletal diversity in hystricognath rodents: functional and phylogenetic aspects. Mammalian Biology, $7^{2}$ (I), 27-44. 
White, J. L. (1993). Indicators of locomotor habits in xenarthrans: evidence for locomotor heterogeneity among fossil sloths. Journal of Vertebrate Paleontology, $\mathbf{1 3}$ (2), 230-242.

Wilson, D. E. and Reeder, D. M. (2005). Mammal Species of the World: a Taxonomic and Geographic Reference. Washington, DC: Smithsonian Institution Press

Wilson, L. A. B. (2013). Allometric disparity in rodent evolution. Ecology and Evolution, 3(4), $97 \mathrm{I}^{-9} 84$.

Wilson, L. A. B. and Sánchez-Villagra, M. R. (2009). Heterochrony and pattens of cranial suture closure in hystricognath rodents. Journal of Anatomy, 214, 339-354.

Wilson, L. A. B. and Sánchez-Villagra, M. R. (20ro). Diversity trends and their ontogenetic basis: an exploration of allometric disparity in rodents. Proceedings of the Royal Society B, 277, 1227-I234.

Wilson, L. A. B., Schradin, C., Mitgutsch, C. et al. (2010). Skeletogenesis and sequence heterochrony in rodent evolution, with particular emphasis on the African striped mouse, Rhabdomys pumilio (Mammalia). Organisms, Diversity \& Evolution, 1o(3), 243-258.

Young, N. M., Wagner, G. P. and Hallgrímsson, B. (2010). Development and the evolvability of human limbs. Proceedings of the National Academy of Sciences, 1o7(8), 3400-3405.

Zelditch, M. L., Swiderski, D. L. and Sheets, D. H. (2004). Morphometrics for Biologists: a Primer. New York: Academic Press. 